\title{
Wintertime organic and inorganic aerosols in Lanzhou, China: sources, processes, and comparison with the results during summer
}

\author{
Jianzhong Xu ${ }^{1}$, Jinsen $\mathrm{Shi}^{2}$, Qi Zhang ${ }^{3}$, Xinlei Ge ${ }^{4}$, Francesco Canonaco ${ }^{5}$, André S. H. Prévôt ${ }^{5,6}$, Matthias Vonwiller ${ }^{7}$, \\ Sönke Szidat ${ }^{7}$, Jinming $\mathrm{Ge}^{2}$, Jianmin $\mathrm{Ma}^{8}$, Yanqing $\mathrm{An}^{1}$, Shichang Kang ${ }^{1}$, and Dahe Qin ${ }^{1}$ \\ ${ }^{1}$ State Key Laboratory of Cryospheric Sciences, Cold and Arid Regions Environmental and Engineering \\ Research Institute, CAS, Lanzhou 730000, China \\ ${ }^{2}$ Key Laboratory for Semi-Arid Climate Change of the Ministry of Education, College of Atmospheric Sciences, \\ Lanzhou University, Lanzhou 730000, China \\ ${ }^{3}$ Department of Environmental Toxicology, University of California, Davis, CA 95616, USA \\ ${ }^{4}$ Jiangsu Key Laboratory of Atmospheric Environment Monitoring and Pollution Control (AEMPC), School of \\ Environmental Science and Engineering, Nanjing University of Information Science \& Technology, Nanjing 210044, China \\ ${ }^{5}$ Laboratory of Atmospheric Chemistry, Paul Scherrer Institute (PSI), Villigen 5232, Switzerland \\ ${ }^{6}$ State Key Laboratory of Loess and Quaternary Geology and Key Laboratory of Aerosol Chemistry and Physics, Institute of \\ Earth Environment, Chinese Academy of Sciences, Xi' an 710075, China \\ ${ }^{7}$ Department of Chemistry and Biochemistry \& Oeschger Centre for Climate Change Research, University of Bern, \\ 3012 Bern, Switzerland \\ ${ }^{8}$ College of Earth Environmental Science, Lanzhou University, Lanzhou 730000, China
}

Correspondence to: Jianzhong Xu (jzxu@lzb.ac.cn)

Received: 31 March 2016 - Published in Atmos. Chem. Phys. Discuss.: 2 May 2016

Revised: 15 November 2016 - Accepted: 16 November 2016 - Published: 5 December 2016

\begin{abstract}
Lanzhou, which is located in a steep alpine valley in western China, is one of the most polluted cities in China during the wintertime. In this study, an Aerodyne high-resolution time-of-flight aerosol mass spectrometer (HR-ToF-AMS), a seven-wavelength aethalometer, and a scanning mobility particle sizer (SMPS) were deployed during 10 January to 4 February 2014 to study the mass concentrations, chemical processes, and sources of submicrometer particulate matter $\left(\mathrm{PM}_{1}\right)$. The average $\mathrm{PM}_{1}$ concentration during this study was $57.3 \mu \mathrm{g} \mathrm{m}^{-3}$ (ranging from 2.1 to $229.7 \mu \mathrm{g} \mathrm{m}^{-3}$ for hourly averages), with organic aerosol (OA) accounting for $51.2 \%$, followed by nitrate $(16.5 \%)$, sulfate $(12.5 \%)$, ammonium (10.3\%), black carbon (BC, $6.4 \%$ ), and chloride (3.0\%). The mass concentration of $\mathrm{PM}_{1}$ during winter was more than twice the average value observed at the same site in summer $2012\left(24.5 \mu \mathrm{g} \mathrm{m}^{-3}\right)$, but the mass fraction of OA was similar in the two seasons. Nitrate contributed a significantly higher fraction to the $\mathrm{PM}_{1}$ mass in winter than summer (16.5\% vs. $10 \%)$, largely due to more favored partitioning to the particle phase at low air
\end{abstract}

temperature. The mass fractions of both $\mathrm{OA}$ and nitrate increased by $\sim 5 \%$ (47 to 52 for $\mathrm{OA}$ and 13 to $18 \%$ for nitrate) with the increase of the total $\mathrm{PM}_{1}$ mass loading, while the average sulfate fraction decreased by $6 \%$ (17 to $11 \%$ ), indicating the importance of OA and nitrate for the heavy air pollution events in Lanzhou. The size distributions of OA, nitrate, sulfate, ammonium, and chloride all peaked at $\sim 500 \mathrm{~nm}$, with OA being slightly broader, suggesting that aerosol particles were internally mixed during winter, likely due to frequently calm and stagnant air conditions during wintertime in Lanzhou (average wind speed: $0.82 \mathrm{~m} \mathrm{~s}^{-1}$ ).

The average mass spectrum of OA showed a medium oxidation degree (average $\mathrm{O} / \mathrm{C}$ ratio of 0.28 ), which was lower than that during summer $2012(\mathrm{O} / \mathrm{C}=0.33)$. This is consistent with weaker photochemical processing during winter. Positive matrix factorization (PMF) with the multi-linear engine (ME-2) solver identified six OA sources, i.e., a hydrocarbon-like OA (HOA), a biomass burning OA (BBOA), a cooking-emitted OA (COA), a coal combustion OA (CCOA), and two oxygenated OA (OOA) factors. 
One of the OOAs was less oxidized (LO-OOA), and the other one more oxidized (MO-OOA). LO-OOA was the most abundant OA component ( $22.3 \%$ of OA mass), followed by CCOA $(22.0 \%)$, COA $(20.2 \%)$, MO-OOA (14.9\%), BBOA $(10.8 \%)$, and HOA $(9.8 \%)$. The mass fraction of primary $\mathrm{OA}(=\mathrm{HOA}+\mathrm{BBOA}+\mathrm{COA}+\mathrm{CCOA})$ increased during high PM pollution periods, indicating that local primary emissions were a main reason for the formation of air pollution events in Lanzhou during winter. Radiocarbon $\left({ }^{14} \mathrm{C}\right)$ measurement was conducted on four $\mathrm{PM}_{2.5}$ filter samples from this study, which allowed for a quantitative source apportionment of organic carbon (OC). The non-fossil sources on average accounted for $55 \pm 3 \%$ of OC, which could be mainly from biomass burning and cooking activities, suggesting the importance of non-fossil sources for the PM pollution in Lanzhou. Together with the PMF results, we also found that a large fraction $(66 \pm 10 \%)$ of the secondary OC was from non-fossil OC.

\section{Introduction}

Frequent haze pollution events in urban areas in China have been a widespread concern in recent years due to their highly adverse health effects, visibility degradation, and climate effects (Chan and Yao, 2008). The Chinese central government has put in extensive efforts to find urgent and suitable control strategies to reduce further deterioration of air quality. Strategies such as promoting energy conservation, emission reduction measures, and new air quality standards $\left(\mathrm{PM}_{2.5}\right.$ currently vs. $\mathrm{PM}_{10}$ in the past) have been implemented in the last 3 years (http://www.gov.cn/zwgk/2013-09/12/content_ 2486773.htm). Many local governments have also launched measures such as shutting down some highly polluting factories and restricting the use of private vehicles to reduce air pollution in their cities. However, air pollution in China is still far from being controlled due to its complex sources and limited knowledge on the multiple pathways leading to secondary aerosol formation and dynamic variation of aerosol mass loading.

Lanzhou, the capital of Gansu Province, is located in the northwest of China and has experienced air pollution issues since the 1960s due to emissions from the petrochemical industry and its valley terrain, which has tended to form stagnant meteorological conditions (Tang et al., 1985; Zhang et al., 2000). Air pollution is still serious and has become more variable in recent years (since 2000) because of fast urbanization and increased energy consumption. The severity of air pollution often reaches maximum intensity during winter due to coal combustion for domestic heating and cooking, similar to the situations in most cities of northern China (Wang et al., 2014). Despite the serious air pollution during winter in Lanzhou, aerosol chemistry, sources, and formation and transformation processes have been poorly documented in the literature, which limits the development and implementation of efficient control strategies.

The chemical and physical properties of atmospheric aerosol particles during winter, especially during haze episode, have been recently investigated in metropolitan cities in eastern China (Sun et al., 2006, 2014; Zhao et al., 2013; Huang et al., 2014). For example, the mean aerosol optical depth at $500 \mathrm{~nm}$ went up to $\sim 0.7$ during the month-long heavy haze pollution episode during January 2013 in Beijing (Bi et al., 2014). The airborne microbes were found in particulate matter (PM) during hazy periods, which may potentially include respiratory microbial allergens and pathogens (Cao et al., 2014). Collection and analysis of filter samples have enabled quantification of the chemical composition of PM using a suite of offline instruments (such as ion chromatography, organic and element carbon analyzers, and inductively coupled plasma mass spectrometry) in the laboratory (He et al., 2001; Zheng et al., 2005; Sun et al., 2006, 2011a; Zhang et al., 2013; Zhao et al., 2013) but are often incapable of capturing details of the atmospheric evolution processes during the typical life cycle of aerosol.

Previous studies on source apportionment of aerosol particles identified dust, traffic, industry, cooking-related activities, and secondary formation as important contributors, although the contributions of individual sources may change drastically with location, season, and different apportionment algorithms (Zheng et al., 2005; Yu et al., 2013; Huang et al., 2014). For example, Zheng et al. (2005) used a chemical mass balance (CMB) receptor model to quantitatively apportion the sources that contribute to fine PM concentration in Beijing and found coal combustion contributed $16 \%$ of fine PM mass in January. By contrast, principal component analysis of the same dataset estimated almost twice the amount of aerosols from coal combustion (Song et al., 2006). Source apportionment techniques, such as positive matrix factorization (PMF), allow us to use thousands of fragment ions for source identification and use the real measurement uncertainties to constrain the fitting, and would thus appear more suitable to identify and apportion PM to their sources (Ulbrich et al., 2009). Compared with the number of aerosol source apportionment studies using PMF in eastern China (e.g., Sun et al., 2013b; Zhang et al., 2013), there have been fewer studies in inland cities of China (Elser et al., 2016), the results of which can be used for intercomparison and understanding the difference of aerosol pollution in different parts of China. In addition, it has been known that a large mass fraction of ambient PM during haze episodes is from fine particles, of which secondary species (some carbonaceous components, sulfate, nitrate, and ammonium) are major components (Zhao et al., 2013). However, the formation and evolution mechanisms of those secondary species were poorly understood, and previous models tended to underestimate the secondary species budget in polluted regions (e.g., Volkamer et al., 2006; Carlton et al., 2010; Hodzic et al., 2016). 
Online instruments based on mass spectrometric techniques, such as the Aerodyne aerosol mass spectrometer (AMS; Jayne et al., 2000), have advantages in probing the fast aerosol chemical processes because the instrument can output data with a large amount of chemical information and its fine time resolution (in minutes) and mass sensitivity (in $\mathrm{ng} \mathrm{m}^{-3}$; Canagaratna et al., 2007). The Aerodyne high-resolution time-of-flight mass spectrometer (HR-ToFAMS) has been widely employed for the chemical characterization of submicron aerosol ( $\mathrm{PM}_{1}$; DeCarlo et al., 2006), which provides online quantitative mass spectra of the nonrefractory (inorganic and organic) aerosol components with high time resolution. Frequently, organic aerosol (OA) can be further analyzed using the PMF algorithm (Ulbrich et al., 2009; Zhang et al., 2011), which can represent the organic mass spectral matrix as a set of source/process-related factor mass spectra and time series. In addition, the carbon isotope technique has been recently applied to quantify the fossil (F)/non-fossil (NF) origins of carbonaceous aerosols, and in combination with AMS-PMF analyses, the assessment of the origin of secondary organic aerosol (SOA) has become possible (Minguillon et al., 2011; Huang et al., 2014; Zotter et al., 2014; Beekmann et al., 2015).

In a previous study, we used an HR-ToF-AMS to investigate the chemical characteristics of $\mathrm{PM}_{1}$ in the urban area of Lanzhou during summer 2012 (Xu et al., 2014). During that study, organics in $\mathrm{PM}_{1}$ were found to mainly originate from traffic, cooking activities, and chemical reactions which produced semivolatile and less-volatile oxygenated OA. Compared to the summer situation, energy consumption for heating is huge during winter, and the dry and stable meteorological conditions in the valley lead to longer aerosol lifetime during winter. Thus aerosols are influenced largely by very different meteorological conditions and chemical processes between the two seasons. More intensive measurements of PM chemical characteristics are needed to better understand aerosol sources, to quantify their lifetime in the atmosphere, and to constrain the uncertainties of their climatic influences. During winter of 2013/2014, we conducted such a study at an urban site of Lanzhou. In this paper, we focus on the chemical speciation of $\mathrm{PM}_{1}$ and source apportionment of OA.

\section{Measurement and methods}

\subsection{Sampling site}

Aerosol particle measurements were conducted from 10 January to 4 February 2014 , at the top floor of a 22-story building ( $\sim 70 \mathrm{~m}$ a.g.1.; $36.05^{\circ} \mathrm{N} ; 103.85^{\circ} \mathrm{W}, 1569 \mathrm{~m}$ a.s.1.) on the campus of Lanzhou University (LZU, Fig. S1a in the Supplement). The campus is located in the Chenguan district of Lanzhou, which is a cultural and educational area. The 22story building sits at the western edge of the campus and faces a south-north arterial road (Fig. S1a). At the campus side of this building, there is a three-story dining hall of Lanzhou University, and over the arterial road side there are many restaurants and residents. The room temperature (T) was kept at $\sim 20^{\circ} \mathrm{C}$ by a central heating radiator. The weather in Lanzhou during the campaign was cold (average $T=0.5^{\circ} \mathrm{C}$ ) and dry (average relative humidity $(\mathrm{RH})=28 \%$ ) and was influenced by the Asian winter monsoon. Because Lanzhou is surrounded by mountains, atmospheric conditions are normally stable with low wind speed (WS, on average $0.82 \mathrm{~m} \mathrm{~s}^{-1}$ during this study). The sampling site represents a typical urban area dominated by residential and commercial use.

\subsection{Instruments}

The physiochemical properties of aerosol particles were monitored in real time by a suite of instruments (Fig. S1b). The sampling inlet, constructed using a 0.5 in. copper tube, stemmed out of the rooftop by about $1.5 \mathrm{~m}$. A $\mathrm{PM}_{2.5} \mathrm{cy}-$ clone (model URG-2000-30EH, URG Corp., Chapel Hill, NC, USA) was used for removing coarse particles. The length of the sampling line was about $5 \mathrm{~m}$. A diffusion dryer was placed upstream of this line to eliminate potential RH effect on particles. The inlet was shared by an Aerodyne HR-ToF-AMS (Aerodyne, Inc., Billerica, MA, USA) for the size-resolved chemical speciation of non-refractory submicrometer PM (NR-PM 1$)$, a single-particle intracavity laser-induced incandescence photometer (SP2, DMT, Inc., Boulder, CO, USA) for refractory black carbon (rBC) measurement, a customer-made scanning mobility particle sizer (SMPS; Wiedensohler et al., 2012) for measuring particle size distribution between 10 and $800 \mathrm{~nm}$, and a $7 \lambda$ aethalometer (model AE31, Magee Scientific, Berkeley, CA, USA) to derive the mass concentration of light-absorbing black carbon (BC) particles. The total air flow rate from the inlet was $\sim 16 \mathrm{~L} \mathrm{~min}^{-1}$, with a vacuum pump drawing the air at a flow rate of 10 and the other $6 \mathrm{~L} \mathrm{~min}^{-1}$ sampled by the instruments. The retention time of particles in the sampling line was less than $2.5 \mathrm{~s}$. A parallel inlet with a $1: 10$ dilution stage was set up for real-time $\mathrm{PM}_{2.5}$ measurement using a tapered element oscillating microbalance (TEOM series 1400a, R\&P, East Greenbush, NY, USA). The roof of the building also hosted instruments for monitoring meteorological parameters such as visibility, air temperature, wind direction, wind speed, and $\mathrm{RH}$. The visibility was measured with a LED-based $(880 \mathrm{~nm})$ forward $\left(42^{\circ}\right)$ scattering visibility sensor (model M6000, Belfort Ins., Maryland, USA).

\subsubsection{HR-ToF-AMS operation}

A detailed description of the principle and design of HRToF-AMS can be found elsewhere (Jayne et al., 2000; DeCarlo et al., 2006). Briefly, HR-ToF-AMS consists of three major sections: the inlet system, the particle sizing vacuum 
chamber, and the particle composition detection section. The combination of a $100 \mu \mathrm{m}$ orifice and an aerodynamic lens in the inlet system is used to focus the airborne particles into a concentrated and narrow beam, and then accelerated into the vacuum chamber $\left(\sim 10^{5}\right.$ torr $)$ modulated by a chopper for measuring aerodynamic size of the particle; Before being detected, the particles are flash-vaporized at $600{ }^{\circ} \mathrm{C}$ and ionized by a $70 \mathrm{eV}$ electron impact, and finally detected by the high-resolution time-of-flight mass spectrometer. The chopper works at three positions alternately, i.e., an open position which transmits the particle beam continuously, a close position which blocks the particle beam completely, and a chopping position which modulates the beam transmission ( $2 \%$ duty cycle). The open and closed positions yield the bulk and background signals for the airborne particle, respectively, while the chopping position modulates the particle beam by spinning chopper wheel $(\sim 150 \mathrm{~Hz})$ to yield size-resolved spectral signals. The mass spectrometer in the detection section works in two modes based on the shape of the ion path, i.e., $V$ mode and $W$ mode, with high sensitivity and high resolution $(\sim 6000 \mathrm{~m} / \Delta \mathrm{m})$, respectively. The highly sensitive V-mode signals are usually used for reporting mass concentration, while the high-chemical-resolution W-mode signals are used for the analyses of mass spectra. The time resolution for both $\mathrm{V}$ and $\mathrm{W}$ modes was $5 \mathrm{~min}$. In $\mathrm{V}$ mode, the instrument switched between the mass spectrum mode and the particle time of flight (PToF) mode every $15 \mathrm{~s}$, spending 6 and $9 \mathrm{~s}$ on each, and cycled 20 times in one run; no PToF data were recorded in $\mathrm{W}$ mode due to low signal-tonoise $(S / N)$ ratios.

The instrument was calibrated for ionization efficiency (IE), inlet flow rate, and particle sizes using the standard procedure described by (Jayne et al., 2000). For example, the size calibration was performed following the general protocol used in the AMS community. We used standard polystyrene latex (PSL) spheres (Duke Scientific Corp., Palo Alto, CA; 100-700 nm) and mono-dispersed ammonium nitrate particles $(100-300 \mathrm{~nm})$. These three calibrations were performed at the beginning, in the middle, and at the end of the field study. Particle-free ambient air was sampled at the end of the study to determine the detection limits (DLs) of individual species and also for adjusting the fragmentation table. Note that since no in situ measurement of gas phase $\mathrm{CO}_{2}$ was conducted, the subtraction of a constant $\mathrm{CO}_{2}$ signal (400 ppm based on the filtered-air measurement in this study) may introduce uncertainties in the quantification of the organic- $\mathrm{CO}_{2}^{+}$signal. However, this artifact was expected to be small (less than $5 \%$ error in organic- $\mathrm{CO}_{2}^{+}$quantification) due to the high OA concentration (Xu et al., 2014). Default relative ionization efficiency (RIE) values were assumed for organics (1.4), nitrate (1.1), sulfate (1.2), and chloride (1.3), while an RIE value of 3.9 was determined for ammonium following the analysis of pure $\mathrm{NH}_{4} \mathrm{NO}_{3}$. The close concentrations between measured ammonium and predicted ammo- nium based on the stoichiometric charge balance between nitrate, sulfate, and chloride (slope $=0.94$, Fig. S4) suggest that these RIE values are suitable for this campaign.

\subsubsection{Operations of other instruments}

The SMPS consisting of a condensation particle counter (CPC; TSI, model 3772) and a differential mobility analyzer (DMA) was deployed at 5 min interval. Sample and sheath flow rates of the DMA were set to 1 and $5 \mathrm{~L} \mathrm{~min}^{-1}$, respectively. The SMPS was calibrated using a PSL standard prior to field measurements.

The SP2 uses an intracavity Nd:YAG laser at $1064 \mathrm{~nm}$ to determine the light-scattering and laser-induced incandescence of individual $\mathrm{rBC}$ (namely material associated with a strongly absorbing component at $1064 \mathrm{~nm}$ ). The SP2 incandescence signal was used to obtain single-particle $\mathrm{rBC}$ mass after calibration with Aquadag standard BC particles. The measured $\mathrm{rBC}$ mass is converted to a mass equivalent diameter, which is termed as the $\mathrm{BC}$ core diameter $\left(D_{\mathrm{c}}\right)$ - the diameter of a sphere containing the same mass of $\mathrm{rBC}$ as measured in the particle. Any measured particle with a detectable incandescence signal is referred to as an $\mathrm{rBC}$ particle, whereas a particle which only exhibits a scattering signal is termed as a non-BC particle. The total $\mathrm{rBC}$ mass loading is reported as the sum of all detected single-particle rBC masses.

The aethalometer measures the optical attenuation (absorbance) of light from LED lamps emitting at seven wavelengths $(370,470,520,590,660,880$, and $950 \mathrm{~nm})$ with a typical half-width of $20 \mathrm{~nm}$. The difference in light transmission through the particle-laden sample spot and a particlefree reference spot of the filter is attributed to the absorption caused by aerosol. The attenuation of light is converted to the $\mathrm{BC}$ mass concentration using wavelength-dependent calibration factors as recommended by the manufacturer. BC was measured using data at $880 \mathrm{~nm}$ using a specific attenuation cross section of $16.6 \mathrm{~m}^{2} \mathrm{~g}^{-1}$ during the campaign. The flow rate was maintained at $4.8 \mathrm{~L} \mathrm{~min}^{-1}$, calibrated using a flow meter. The detection limit of the aethalometer $\mathrm{BC}$ was determined to be $0.16-0.28 \mu \mathrm{g} \mathrm{m}^{-3}$ with a flow rate of $4.8 \mathrm{LPM}$ and 5 min time intervals, calculated as 3 times the standard deviation $(3 \sigma)$ of the dynamic blanks. The TEOM was operated at a temperature of $40^{\circ} \mathrm{C}$, different than normal operation conditions $\left(50^{\circ} \mathrm{C}\right)$, to dry the aerosol in order to minimize mass loss due to volatilization of semivolatile aerosol compounds. The time resolution of $\mathrm{PM}_{2.5}$ mass concentration was $5 \mathrm{~min}$.

\subsection{Data processing}

\subsubsection{General AMS data processing}

The HR-ToF-AMS data were processed using the standard software of SQUIRREL (v1.56) and PIKA (v1.15c; $\mathrm{http} / / /$ cires.colorado.edu/jimenez-group/) to determine the 
Table 1. Comparison of the composition of category ions and elemental composition of OA between winter 2013/2014 and summer 2012.

\begin{tabular}{lrr}
\hline Category ions & Winter 2014 & Summer 2012 \\
\hline $\mathrm{C}_{x} \mathrm{H}_{y}^{+}$ & $59 \%$ & $56 \%$ \\
$\mathrm{C}_{x} \mathrm{H}_{y} \mathrm{O}_{1}^{+}$ & $26 \%$ & $27 \%$ \\
$\mathrm{C}_{x} \mathrm{H}_{y} \mathrm{O}_{2}^{+}$ & $10 \%$ & $11 \%$ \\
$\mathrm{C}_{x} \mathrm{H}_{y} \mathrm{~N}_{p}^{+}$ & $2 \%$ & $3 \%$ \\
$\mathrm{C}_{x} \mathrm{H}_{y} \mathrm{~N}_{p} \mathrm{O}_{z}^{+}$ & 0 & $1 \%$ \\
$\mathrm{H}_{y} \mathrm{O}_{1}^{+}$ & $2 \%$ & $2 \%$ \\
\hline Elemental & & \\
composition & & \\
\hline $\mathrm{C}$ & $67 \%$ & $59 \%$ \\
$\mathrm{H}$ & $9 \%$ & $7 \%$ \\
$\mathrm{O}$ & $23 \%$ & $26 \%$ \\
$\mathrm{~N}$ & $1 \%$ & $1 \%$ \\
\hline
\end{tabular}

mass concentrations and the size distributions of the NR$\mathrm{PM}_{1}$ species and the ion-speciated mass spectra of organics, written in IGOR (Wavemetrics, Inc., Lake Oswego, OR, USA). An empirical particle collection efficiency (CE) of 0.5 was used, which has been widely used in field studies employing AMS with a dryer installed in front of the equipment's particle inlet. This $\mathrm{CE}$ value was further validated by the consistency and reasonable slope between HR-ToFAMS-measured mass concentrations and SMPS-determined particle volumes (Sect. 3.1.2, $R^{2}=0.9$, slope $=1.48$ ). The elemental ratios of $\mathrm{OA}(\mathrm{O}: \mathrm{C}, \mathrm{H}: \mathrm{C}$, and $\mathrm{OM}: \mathrm{OC})$ for this study were determined using the "Aiken ambient" method (Aiken et al., 2008) other than the "improved-ambient" method (Canagaratna et al., 2015), which increased $\mathrm{O}: \mathrm{C}$ on average by $27 \%, \mathrm{H}: \mathrm{C}$ on average by $10 \%$, and $\mathrm{OM}$ : OC on average by $7 \%$ (Fig. S2). These Aiken ambient results of elemental ratios are more suitable here to allow for comparison with those during summer 2012. In addition, the concentration of polycyclic aromatic hydrocarbon (PAH) was generated in the SQUIRREL panel based on the default fragmentation table (Dzepina et al., 2007).

\subsubsection{Positive matrix factorization (PMF) analyses}

The source decomposition of organics was analyzed by PMF with the multilinear engine (ME-2) algorithm, which serves to reduce rotational ambiguity within the PMF2 algorithm. The ME-2 algorithm allows the user to add a priori information into the model (e.g., source profiles) to constrain the matrix rotation and separate the mixed solution or the weak solution. The PMF analysis of organic matrix using the ME-2 algorithm is implemented within the toolkit SoFi (Source Finder) and perform by the so-called a-value approach (Canonaco et al., 2013). First, organic matrix was analyzed using the PMF2.exe algorithm in robust mode
(Paatero and Tapper, 1994) and explored using the PMF Evaluation Toolkit (PET; Ulbrich et al., 2009). The PMF solution was evaluated following the procedures outlined in Table 1 of Zhang et al. (2011) including modification of the error matrix and down weight of low- $S / N$ ions. Moreover, based on the AMS fragmentation table, some organic ions were not directly measured but scaled to the organic signal at $m / z 44$, which were down-weighted by increasing their errors by a factor of 3 . The results of four-, five-, and sixfactor solutions with $f$ peak at 0 are shown in the Supplement (Figs. S5-S7). It is easy to find that a coal-combustionemitted OA (CCOA) factor, a cooking-emitted OA (COA) factor, and less-oxidized and more-oxidized OA (LO-OOA and MO-OOA) factors could be clearly separated in the fourfactor solution; for the CCOA factor, there were significant contributions from $m / z 55,57,60,73,91$, and 115 in the mass spectrum, suggesting a mixing of multiple sources. In the five-factor solution, a hydrocarbon-like OA (HOA) factor was separated; however, $m / z 60$ and 73, which are related to biomass burning OA (BBOA), could not be separated. We then performed OA source apportionment using the ME-2 algorithm by constraining the profiles of HOA and BBOA with the fixed a-value of 0.1 for HOA and 0.4 for BBOA. The avalue test was performed following the technical guidelines presented in Crippa et al. (2014). The reference profile of HOA was adopted from the HOA of the summer study, and the reference profile of BBOA was adopted from the ninefactor PMF solution of this study.

The size distributions of individual OA factors were determined via a multivariate linear regression technique (Ge et al., 2012). This algorithm assumes that each OA mass spectrum is the linear superposition of the mass spectra of individual OA factors, whose mass profiles are constant across the whole size range. Further details about the algorithm can be found in Xu et al. (2014).

\subsubsection{Radiocarbon $\left({ }^{14} \mathrm{C}\right)$ data analysis}

In order to identify the origins of SOA, we conducted ${ }^{14} \mathrm{C}$ analysis on four filter samples. These filter samples were collected at the Cold and Arid Regions Environmental and Engineering Research Institute (CAEERI) site, which is about $500 \mathrm{~m}$ away from the LZU site (Fig. S1a). Filter samples were collected using a low-volume $\mathrm{PM}_{2.5}$ sampler $\left(16.7 \mathrm{~L} \mathrm{~min}^{-1}\right)$ during January 2014 with a $24 \mathrm{~h}$ sampling time every week for each filter (3, 8, 15, and 23 January) on pre-baked quartz filters. One field blank filter was collected and analyzed to correct the filter sample measurements. Here, we use the results of these four filter samples to roughly represent the average situation of the field sampling because of the relatively stable meteorological conditions (Sect. 3.1.1) and similar aerosol sources during the field study (Sect. 3.1.3). Due to the limitation of the small amount of filter samples, the results based on these carbon isotopic data are preliminary, and comprehensive validation is an on- 


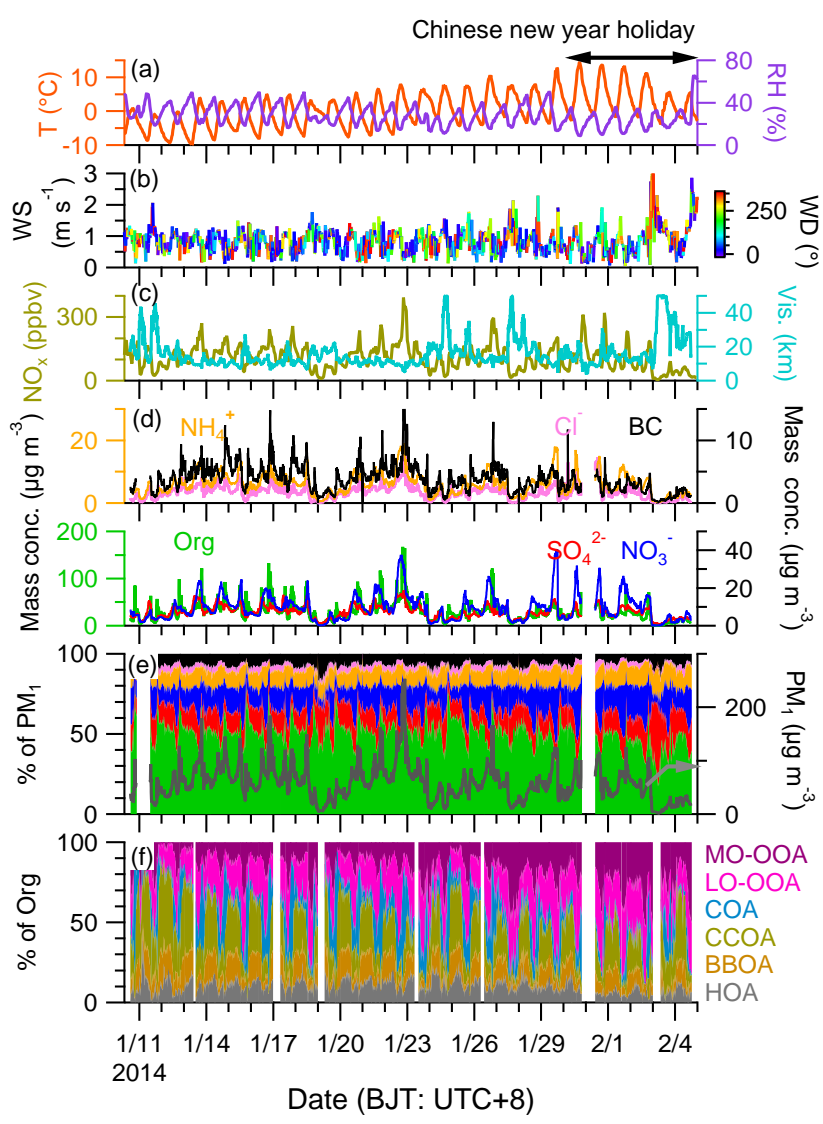

Figure 1. Summary of meteorological and aerosol species data. (a) air temperature $(T)$ and relative humidity $(\mathrm{RH})$, (b) wind speed (WS) colored by wind direction (WD), (c) $\mathrm{NO}_{x}$ and visibility, (d) mass concentration of $\mathrm{PM}_{1}$ species, (e) the mass contribution of PM1 species (BC is from aethalometer measurement), and (f) the mass contribution of organic components to organic aerosol. Note that $\mathrm{BC}$ is from aethalometer measurement.

going undertaking. Organic carbon (OC) was separated from the filters by combustion at $375^{\circ} \mathrm{C}$ during $200 \mathrm{~s}$ in pure oxygen in a thermo-optical OC-elemental carbon (EC) analyzer (Model 4L, Sunset Laboratory Inc, USA; Zhang et al., 2012). The carbon isotopic analysis was conducted by online coupling of the OC-EC analyzer with the accelerator mass spectrometry system at the University of Bern, Switzerland (Szidat et al., 2014; Zotter et al., 2014; Agrios et al., 2015). Fossil ${ }^{14} \mathrm{C}$ measurement results were transferred into the nonfossil fraction $\left(f_{\mathrm{NF}}\right)$ of $\mathrm{OC}$ using a conversion factor of 1.03 (Zhang et al., 2015b).

For the apportionment of AMS-PMF OA factors using ${ }^{14} \mathrm{C}$ data (Zotter et al., 2014), we assume that all OC sources are represented by the six PMF factors and that the $f_{\mathrm{NF}}$ in NR-PM 1 was the same as that in $\mathrm{PM}_{2.5}$. The OA mass of each PMF factor and total OA were first converted to $\mathrm{OC}$ mass using the $\mathrm{OM}: \mathrm{OC}$ ratios derived from its $\mathrm{MS}\left(\mathrm{OM}: \mathrm{OC}_{\mathrm{HOA}}=1.29\right.$; $\mathrm{OM}: \mathrm{OC}_{\mathrm{BBOA}}=1.5 ; \mathrm{OM}: \mathrm{OC}_{\mathrm{COA}}=1.27 ; \mathrm{OM}: \mathrm{OC}_{\mathrm{CCOA}}=$
$1.37 ; \mathrm{OM}: \mathrm{OC}_{\mathrm{LO}-\mathrm{OOA}}=1.55 ; \mathrm{OM}: \mathrm{OC}_{\mathrm{MO}-\mathrm{OOA}}=2.01 ;$ $\mathrm{OM}: \mathrm{OC}_{\text {total }}=1.51$ ). For the $\mathrm{OC}$ mass concentration of the AMS factors, the notations hydrocarbon-like organic carbon (HOC), biomass burning organic carbon (BBOC), cooking organic carbon (COC), coal combustion organic carbon (CCOC), oxygenated organic carbon (OOC), and total organic carbon from AMS (TOC $\mathrm{TMS}_{\mathrm{A} S}$ ) were adopted in the following sections. An $f_{\mathrm{NF}}$ value was assumed a priori for the primary PMF factors $\mathrm{HOC}, \mathrm{BBOC}, \mathrm{COC}$, and $\mathrm{CCOC}$. The average $f_{\mathrm{NF}}$ of $\mathrm{OOC}$ is then derived by the equation below:

$$
\begin{aligned}
f_{\mathrm{NF} \_\mathrm{OOC}} & =\left(\mathrm{TOC}_{\mathrm{NF} \_\mathrm{AMS}}-f_{\mathrm{NF} \_\mathrm{HOC}} \times \mathrm{HOC}\right. \\
& -f_{\mathrm{NF}_{-} \mathrm{BBOC}} \times \mathrm{BBOC}-f_{\mathrm{NF} \_\mathrm{COC}} \times \mathrm{COC} \\
& \left.-f_{\mathrm{NF}_{-} \mathrm{CCOC}} \times \mathrm{CCOC}\right) /(\mathrm{SV}-\mathrm{OOC}+\mathrm{LV}-\mathrm{OOC}) .
\end{aligned}
$$

Here $\mathrm{HOC}$ is assumed to originate from gasoline and diesel exhaust and consists exclusively of fossil carbon; i.e., $f_{\mathrm{NF}_{-} \mathrm{HOC}}=0$. $\mathrm{BBOC}$ is estimated to be originated from biomass burning; i.e., $f_{\mathrm{NF} \_\mathrm{BBOC}}=1$. $\mathrm{COC}$ is assumed to originate from non-fossil carbon such as cooking oil and dressing; i.e., $f_{\mathrm{NF}-\mathrm{COC}}=1$. CCOC is estimated to originate from coal combustion; i.e., $f_{\mathrm{NF}_{-} \mathrm{CCOC}}=0$.

\section{Results and discussions}

\subsection{Overview of field study}

\subsubsection{Meteorological conditions}

Figure 1 shows the time series of meteorological parameters and $\mathrm{PM}_{1}$ components during the campaign. The measurement site mainly received air masses from the north and northeast, associated with low WSs ranging from 0.6 to $1.1 \mathrm{~m} \mathrm{~s}^{-1}$ (daily average: $0.8 \pm 0.2 \mathrm{~m} \mathrm{~s}^{-1}$ ). The mountains to the north and south of the city could significantly reduce the wind speeds. Air temperature ranged from -5.0 to $6.6^{\circ} \mathrm{C}$ (average $=0.6 \pm 3.9^{\circ} \mathrm{C}$ ) for the diurnal variation during the campaign but had an evident increase after the Chinese New Year (31 January 2014; Fig. 1a). No precipitation event occurred during the campaign, and RH was pretty low, ranging from 16.8 to $39.5 \%$ (daily average $=27.5 \pm 7.4 \%$ ) for the diurnal variation. Overall, the meteorological conditions during the campaign were much stabler and dryer than those during summer 2012 (on average: $1.2 \pm 0.6 \mathrm{~m} \mathrm{~s}^{-1}$ for WS and $60 \pm 17 \%$ for $\mathrm{RH})$.

\subsubsection{Intercomparisons}

The intercomparisons of AMS vs. SMPS and TEOM are shown in Fig. S3. The mass concentration of $\mathrm{PM}_{1}$ and the volume of particle measured by SMPS are tightly correlated $\left(R^{2}=0.9\right)$ with a slope of 1.48 , which represents the average density of bulk particles, assuming that the AMS and the SMPS measure a similar particle population. This value is indeed very close to the estimated $\mathrm{PM}_{1}$ density (1.46) based on 
(a)

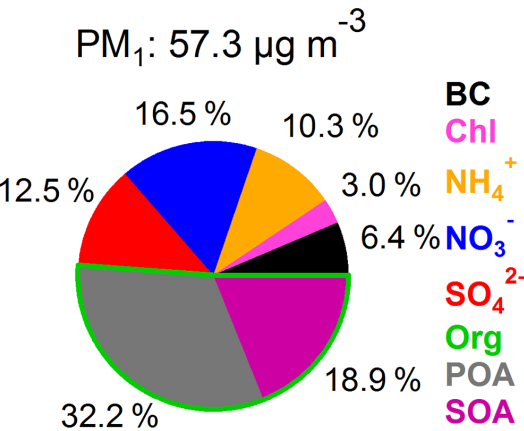

(b)

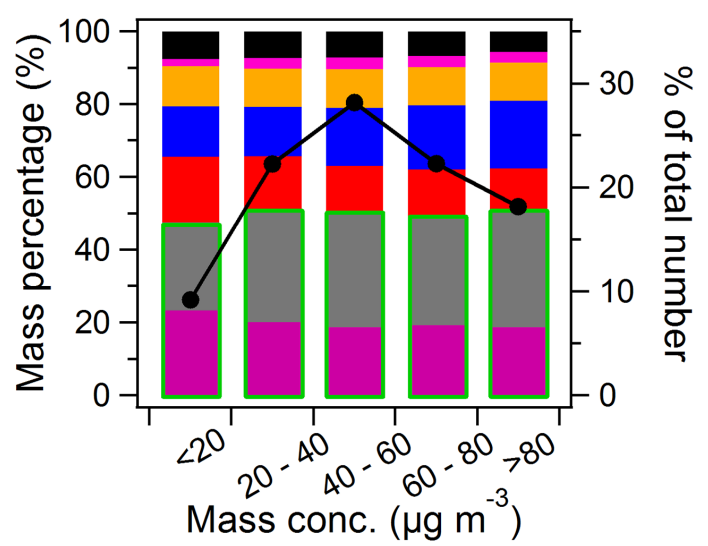

Figure 2. The average mass contribution of $\mathrm{PM}_{1}$ (=NR$\mathrm{PM}_{1}+\mathrm{BC}$ ) species (a) during the whole sampling period and (b) as a function of the $\mathrm{PM}_{1}$ mass concentration $\left(\mu \mathrm{g} \mathrm{m}^{-3}\right)$ bins (left). The right axis in (b) shows the percentage of the data number in each bin to the total data number. The organics were decomposed into primary organic aerosol (POA) and secondary organic aerosol (SOA) using PMF (Sect. 3.4).

the measured particle composition for this study (using density of 1.2 for organics, $1.72 \mathrm{~g} \mathrm{~m}^{-3}$ for $\mathrm{NH}_{4} \mathrm{NO}_{3}, 1.77$ for $\left(\mathrm{NH}_{4}\right)_{2} \mathrm{SO}_{4}, 1.52$ for $\mathrm{NH}_{4} \mathrm{Cl}$, and $1.8 \mathrm{~g} \mathrm{~m}^{-3}$ for BC; Zhang et al., 2005; Bond and Bergstrom, 2006). The mass concentration of $\mathrm{PM}_{1}$ is also closely correlated $\left(R^{2}=0.71\right)$ with TEOM $\mathrm{PM}_{2.5}$ concentrations with a slope of 0.73. Similar contributions of $\mathrm{PM}_{1}$ to $\mathrm{PM}_{2.5}$ were also observed in other cities in China during winter (Elser et al., 2016), such as Beijing (0.74 during 2011; Sun et al., 2013b). Note that the actual mass ratio between $\mathrm{PM}_{1}$ and $\mathrm{PM}_{2.5}$ should be higher than these values since refractory materials such as crustal components were not measured.

\subsection{3 $\mathrm{PM}_{1}$ composition, variation, and acidity}

The average mass concentration of $\mathrm{PM}_{1}\left(\mathrm{NR}-\mathrm{PM}_{1}+\mathrm{BC}\right)$ was $57.3 \mu \mathrm{g} \mathrm{m}^{-3}$ (ranging from 2.1 to $229.7 \mu \mathrm{g} \mathrm{m}^{-3}$ for hourly average) during this study, with 51.2 organics, 16.5 nitrate, 12.5 sulfate, 10.3 ammonium, $6.4 \mathrm{BC}$, and $3.0 \%$ chloride (Fig. 2a). The average mass concentration was more than twice the average value observed during summer 2012 $\left(24.5 \mathrm{\mu g} \mathrm{m}^{-3}\right)$. All species showed similar day-to-day variation, with nitrate being the most significant one (Fig. 1e), suggesting an important local source for nitrate. The mass contributions of $\mathrm{PM}_{1}$ species from low to high $\mathrm{PM}_{1}$ concentrations showed an increased contribution for organics (49 to $53 \%$ ) and nitrate (13 to $18 \%$ ), but a decreased contribution for sulfate ( 17 to $11 \%$ ) and BC (7.3 to $5.3 \%$ ), suggesting somewhat different chemical processes/sources for each species during the haze pollution (Fig. 2b). Specifically, the increased organics were mainly due to the contribution of primary OA (POA) based on PMF analysis (more discussions are given in Sect. 3.5). During the late part of the Chinese New Year holiday (3 February to end of the study), $\mathrm{PM}_{1}$ concentration decreased in association with increased wind speed ( $\sim 1$ to $2 \mathrm{~m} \mathrm{~s}^{-1}$ ). NR-PM 1 appeared to be neutralized throughout this study, as indicated by an overall stoichiometric charge balance between the anions (i.e., nitrate, sulfate, and chloride) and the cation ammonium (slope $=0.94$, Fig. S4). This result indicates that the inorganic particulate species were mainly present in the forms of $\mathrm{NH}_{4} \mathrm{NO}_{3}$, $\left(\mathrm{NH}_{4}\right)_{2} \mathrm{SO}_{4}$, and $\mathrm{NH}_{4} \mathrm{Cl}$ in $\mathrm{PM}_{1}$.

\subsubsection{Size distribution}

The average chemically resolved size distributions of NR$\mathrm{PM}_{1}$ species are shown in Fig. 3a. While all components peaked between 400 and $500 \mathrm{~nm}$, organic aerosol presented a wider distribution than the inorganics and extended to $\sim 250 \mathrm{~nm}$, suggesting the influence of fresh organics (POA; more discussions are given in Sect. 3.4). These features were similar to those found in most urban sites by the AMS. The similar mode size of inorganics and SOA (Fig. 3c) suggested the internally well-mixed air mass during the sampling period. The mass contributions of chemicals at the major peak $(400-500 \mathrm{~nm})$ were organics $(\sim 50 \%)$, nitrate $(\sim 20 \%)$, ammonium $(\sim 15 \%)$, sulfate $(\sim 10 \%)$, and chloride $(\sim 5 \%)$, while the contribution of organics increased with the decreasing of size mode (Fig. 3c). Comparing with the results observed during summer 2012, the size distributions of aerosol particles during winter were narrower, although the mode sizes of major peaks were similar, indicating highly mixed and aged aerosol particles during winter. Note that chloride also showed a wider distribution which was more similar to organics other than sulfate and nitrate. This was not observed during summer 2012 and could be related to OA emitted from coal combustion and biomass burning during wintertime. Note that chloride also showed a wider distribution which was more similar to organics other than sulfate and nitrate. This was not observed during summer 2012 and could be related to OA emitted from coal combustion and biomass burning during wintertime. 


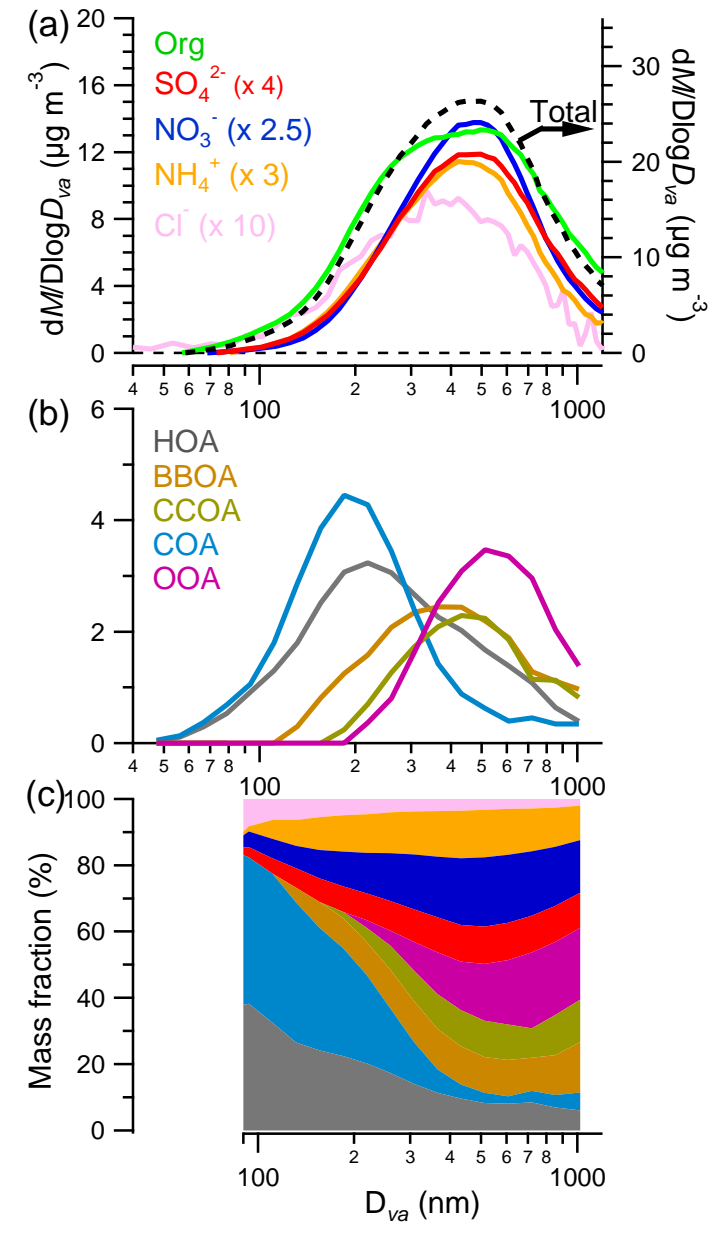

Figure 3. The size distributions of (a) NR-PM 1 species, (b) organic components, and (c) mass contribution of all species to NR-PM 1 .

\subsection{Diurnal variations of aerosol species}

All species show significant diurnal variations during the study, suggesting the important local and regional sources of aerosol (Fig. 4). The observed diurnal trends of BC presented two dominant peaks, with one in the late morning (10:0012:00) and another in the early evening (20:00-22:00). The morning peak did not overlap with rush hour (07:00-9:00), different than that of summer 2012; the BC mass loading started to increase from 06:00 continuously during the morning, reached a maximum between 10:00 and 12:00, and then dropped down after noontime. Another combustion tracer, carbon monoxide (CO), also showed a similar morning peak (Fig. 5). This morning peak likely resulted from the contribution of multiple combustion sources - such as coal combustion, biomass burning, and traffic emission, which had different morning peaks (see Sect. 3.4) - and the formation of an inversion layer during winter at Lanzhou which promoted accumulation of air pollutants from enhanced human activities in the morning. This inversion layer frequently formed

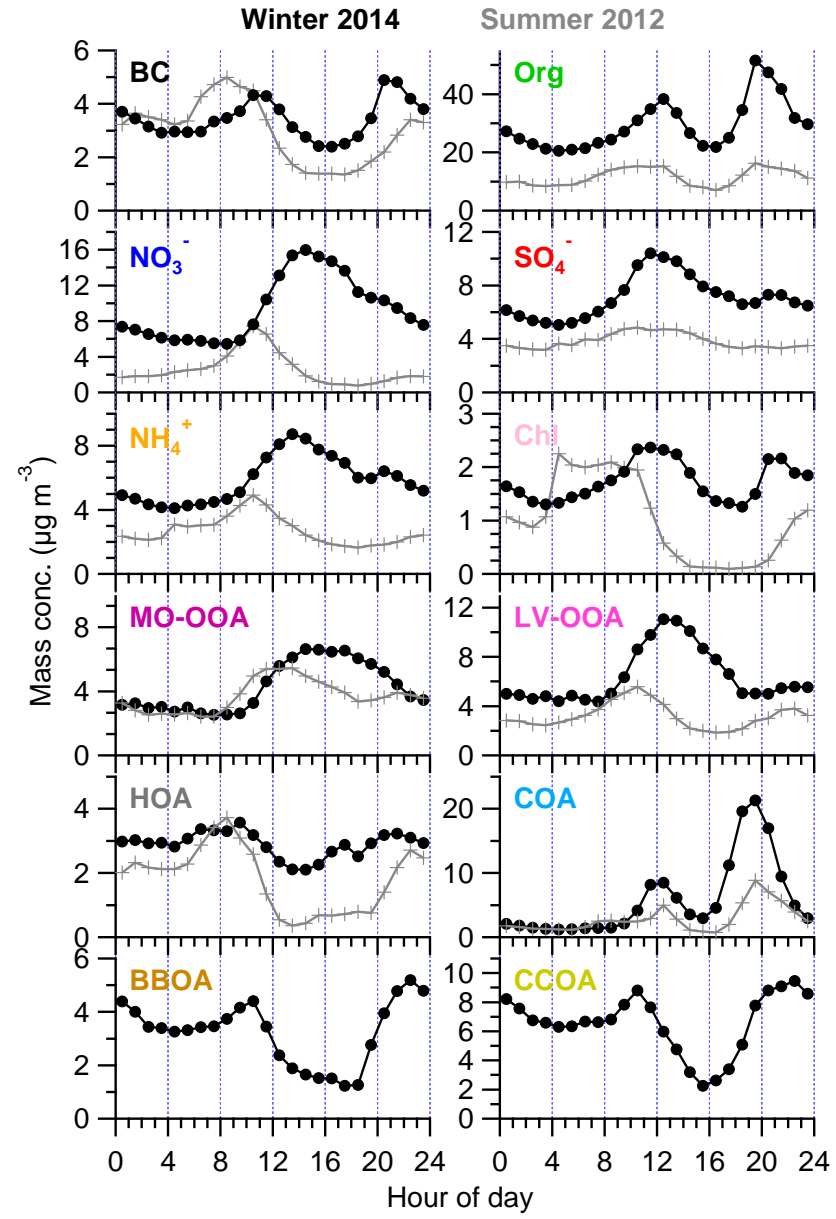

Figure 4. The diurnal variation of $\mathrm{PM}_{1}$ species during winter 2013/2014 and summer 2012.

in the nighttime and diffused after noontime due to the valley terrain (Zhang and $\mathrm{Li}, 2011$ ). The temperature profile observed at the suburban Lanzhou site (Yuzhong, $\sim 30 \mathrm{~km}$ from the sampling site) showed a strong inversion in the low boundary layer during the morning time (Fig. S8). But such influences should be further verified in the future with simultaneous measurements from boundary layer heights. The evening peak of $\mathrm{BC}$ could result from increased human activities such as traffic, cooking, and heating coupled with the low boundary layer after sunset. Organics had two sharp peaks at noontime (12:00-13:00) and in the early evening (19:00-20:00) which correspond to lunchtime and dinnertime, respectively, indicating the importance of cookingrelated emissions of OA. PMF analysis shows that cookingemitted aerosol could contribute up to $50 \%$ of organics during mealtimes (Sect. 3.4.3).

Sulfate presented two peaks, with one occurring at noontime (11:00-14:00) in accordance with the photochemical processes; this peak is narrower than that during summer, likely due to relatively weak photochemical activities. Another minor peak occurred between 20:00 and 22:00, which 


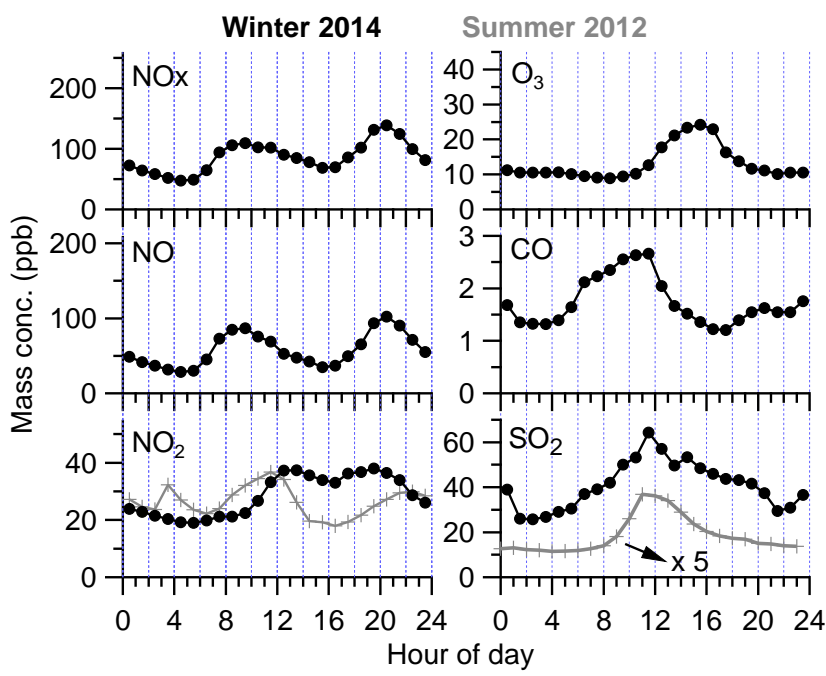

Figure 5. The diurnal variations of gas species downloaded from the MEP-China station during winter 2013/2014 and summer 2012.

was likely due to the lowered boundary layer depth. The significantly higher concentration of sulfate during winter than summer could result from a higher amount of precursor $\mathrm{SO}_{2}$ emission, wintertime hydroxyl radical formation, and the increased aerosol particle surface due to high PM loadings that facilitated the heterogonous conversion of $\mathrm{SO}_{2}$ to sulfate (Young et al., 2012; Pusede et al., 2015; Zheng et al., 2015). The diurnal pattern of sulfate during winter was similar to that of summer 2012 at Lanzhou and summer 2011 at Beijing but was different from that of Beijing during winter 2011/2012, where aqueous processing was found to possibly play an important role (Sun et al., 2013b). Chloride had a similar diurnal pattern to sulfate, although the evening peak was more obvious. The major source of hydrochloric acid is biomass burning, coal combustion, and waste combustion (Ianniello et al., 2011). The significant evening peak could be related to these sources coupled with the shallow boundary layer. The high background concentrations of chloride during day and night suggests a persistent emission of hydrochloric acid, which could be from the heating factory and power plants. The diurnal pattern of chloride during winter was different from that during summer 2012, which peaked during the nighttime due to temperature-dependent gas-particle partitioning. Nitrate peaked between 12:00 and 16:00, right after the peak of sulfate. The formation of nitrate during afternoon suggests that nitrate was dominated by the homogeneous photochemical production. Figure 5 shows the variations of $\mathrm{NO}_{x}$ and $\mathrm{O}_{3}$ calculated from data downloaded from one station monitored by the Ministry of Environmental Protection of China (MEP), $\sim 3 \mathrm{~km}$ southwest of the sampling site (Fig. S1a); NO had a morning peak (07:0010:00) and an evening peak (19:00-21:00), corresponding to rush hour; $\mathrm{NO}_{2}$, which formed from $\mathrm{NO}$ consumed by $\mathrm{O}_{3}$, increased from 10:00 and slightly decreased from 14:00 to

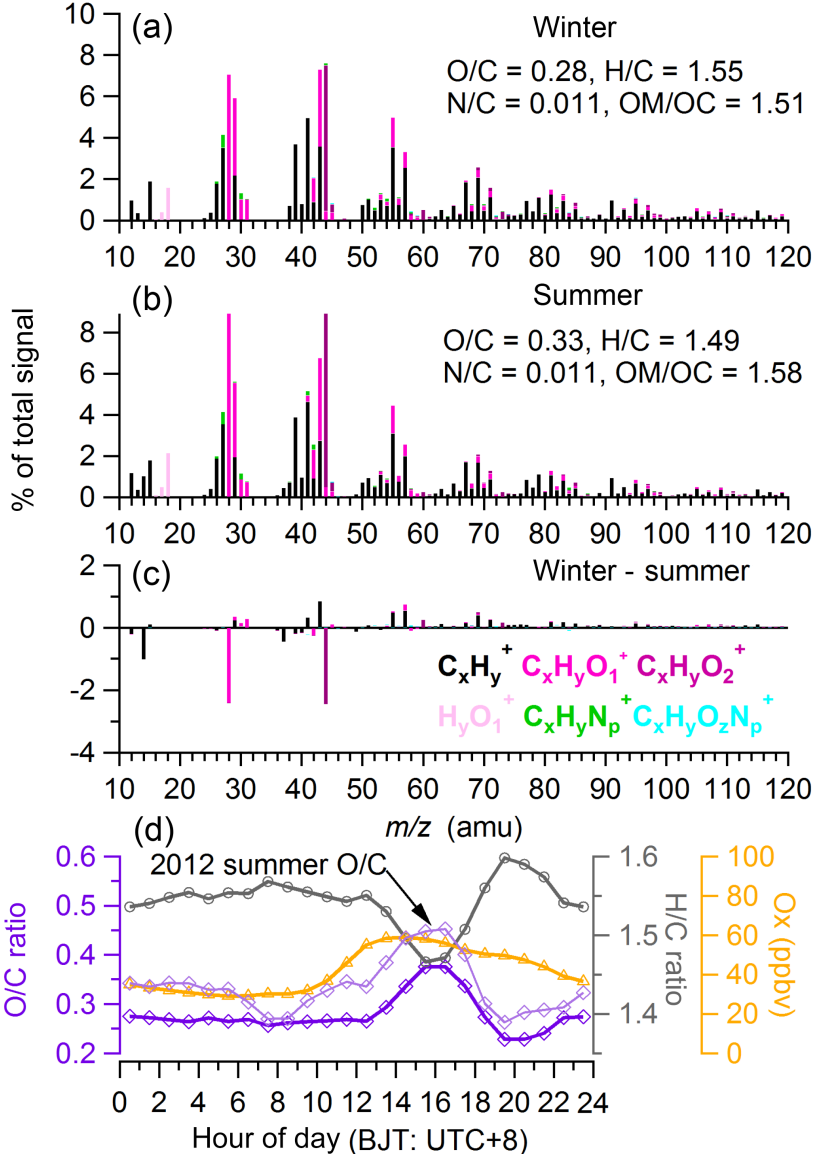

Figure 6. The average HR-MS and elemental ratios of organics for (a) this study, (b) summer 2012, (c) the HR-MS difference between this study and summer 2012, and (d) the diurnal variations of elemental ratios and odd oxygen $\left(\mathrm{O}_{x}=\mathrm{NO}_{2}+\mathrm{O}_{3}\right)$.

18:00, corresponding to the photolysis of $\mathrm{NO}_{2}$ and the formation of nitric acid during afternoon. Note that during nighttime the diurnal variation of $\mathrm{O}_{3}$ still showed a background $(\sim 10 \mathrm{ppb})$, although the concentrations of NO were up to $50 \mathrm{ppb}$. This inconsistency was likely due to the instrument drift in the MEP station during long-term observation; however it seemed that the pattern and the amplitude of the diurnal variation of $\mathrm{O}_{3}$ were reasonable. The diurnal change of $\mathrm{NO}_{x}\left(\Delta \mathrm{NO}_{x}\right)$ mixing ratio was $\sim 50 \mathrm{ppbv}$ (from 150 to $100 \mathrm{ppbv}$ ), while the diurnal change of the sum of $\Delta \mathrm{O}_{3}$ and $\Delta \mathrm{NO}_{3}^{-}$was $\sim 30 \mathrm{ppbv}$. Considering the higher mixing-layer height during the afternoon, it seems that nitrate was mainly formed from the photochemical processing of $\mathrm{NO}_{x}$. The diurnal pattern of nitrate during winter was vastly different from that during summer 2012, which was mainly controlled by the dynamic of mixing layer and gas-particle partitioning.

\subsubsection{Bulk characteristics and elemental ratios of $\mathrm{OA}$}

Table 1 shows the average elemental mass composition and mass contributions of six ion categories to the total organ- 
Table 2. Coefficient of determination $\left(R^{2}\right)$ between time series of OA factors and other aerosol species. Values indicating a strong correlation (i.e., $R^{2}>0.6$ ) are in bold.

\begin{tabular}{lrrrrrrrr}
\hline$R^{2}$ & HOA & BBOA & COA & CCOA & LO-OOA & MO-OOA & POA* & SOA* \\
\hline BC & $\mathbf{0 . 6 4}$ & $\mathbf{0 . 6 7}$ & 0.24 & 0.59 & 0.20 & 0.06 & $\mathbf{0 . 6 4}$ & 0.16 \\
PAH & 0.40 & $\mathbf{0 . 6 4}$ & 0.25 & 0.58 & 0.02 & 0.00 & $\mathbf{0 . 6 1}$ & 0.01 \\
Sulfate & 0.35 & 0.24 & 0.17 & 0.22 & $\mathbf{0 . 7 1}$ & 0.34 & 0.32 & $\mathbf{0 . 6 4}$ \\
Nitrate & 0.19 & 0.04 & 0.15 & 0.02 & $\mathbf{0 . 7 4}$ & $\mathbf{0 . 7 1}$ & 0.16 & $\mathbf{0 . 8 5}$ \\
Chloride & 0.52 & 0.52 & 0.19 & 0.49 & 0.45 & 0.13 & 0.50 & 0.35 \\
Sulfate + nitrate & 0.27 & 0.10 & 0.18 & 0.07 & $\mathbf{0 . 8 1}$ & $\mathbf{0 . 6 2}$ & 0.23 & $\mathbf{0 . 8 5}$ \\
Sulfate + nitrate + chloride & 0.35 & 0.18 & 0.19 & 0.15 & $\mathbf{0 . 7 7}$ & 0.52 & 0.32 & $\mathbf{0 . 7 7}$ \\
\hline
\end{tabular}

$* \mathrm{POA}=\mathrm{HOA}+\mathrm{BBOA}+\mathrm{COA}+\mathrm{CCOA} ; \mathrm{SOA}=\mathrm{LO}-\mathrm{OOA}+\mathrm{MO}-\mathrm{OOA}$.

ics. Carbon contributed $67 \%$ of the organics, followed by oxygen $(23 \%)$, hydrogen $(9 \%)$, and nitrogen $(1 \%)$; correspondingly, $\mathrm{C}_{x} \mathrm{H}_{y}^{+}$dominated the organics by $59 \%$, followed by $\mathrm{C}_{x} \mathrm{H}_{y} \mathrm{O}_{1}^{+}(26 \%), \mathrm{C}_{x} \mathrm{H}_{y} \mathrm{O}_{2}^{+}(10 \%), \mathrm{H}_{y} \mathrm{O}_{1}^{+}(2 \%)$, and $\mathrm{C}_{x} \mathrm{H}_{y} \mathrm{~N}_{p}^{+}(2 \%)$. Compared with the results of summer 2012 , the organics in winter had higher carbon $(67 \%$ vs. $59 \%$ ) and $\mathrm{C}_{x} \mathrm{H}_{y}^{+}$content (59\% vs. $56 \%$ ), and lower oxygen content ( $23 \%$ vs. $26 \%$; Fig. 6c); this suggests that the organics during winter had a higher fraction of primary compounds than those during summer, which was likely due to weaker photochemical activities, lower boundary layer height, and more emissions from primary sources. The average $\mathrm{O} / \mathrm{C}$ of organics, an indicator for oxidation state, was 0.28 during this study, which was somewhat lower than that of summer 2012 (0.33; Fig. 6a and b). Photochemical processing of organics during winter appeared to be significantly weaker and shorter than those during summer as shown by the smaller diurnal peak of $\mathrm{O} / \mathrm{C}$ (Fig. 6d). In addition, an offset existed for the $\mathrm{O} / \mathrm{C}$ diurnal variation between the 2012 and 2014 studies especially for nighttime, which suggested that background/residual aerosol in the summer were more oxidized than in the winter. The diurnal profile of $\mathrm{H} / \mathrm{C}$ was inversely correlated with that of $\mathrm{O} / \mathrm{C}$, and the peaking of organic aerosol concentration usually corresponded to the high $\mathrm{H} / \mathrm{C}$ ratio and low $\mathrm{O} / \mathrm{C}$ ratio, indicating the dominant role of primary $\mathrm{OA}$.

\subsection{Source apportionment of $\mathrm{OA}$}

Source apportionment via PMF with the ME-2 engine on OA mass spectra resolved six components, i.e., HOA, COA, CCOA, BBOA, LO-OOA, and MO-OOA. Each component has a unique mass spectral pattern, diurnal pattern, and temporary variation, which correlated with corresponding tracers such as inorganic species. Two OOA components can be regarded as surrogates of SOA, with MO-OOA for more aged SOA and LO-OOA for fresher SOA; the HOA, BBOA, COA, and CCOA components are regarded as POA based on their low $\mathrm{O} / \mathrm{C}$ ratios and good correlations with primary aerosol tracers (Fig. 7). In comparison with the source apportionment results of summer 2012, the organic sources and chemical processes during winter 2013/2014 were more complex due to the multiple primary sources. Detailed discussion of each factor is given in the following subsections.

\subsubsection{HOA}

HOA factors had been frequently separated from the OA in urban area due to the emission from traffic and/or other fossil combustion activities (e.g., Sun et al., 2011b; Ge et al., 2012). The diurnal pattern of HOA in winter 2013/2014 of Lanzhou shows two predominant peaks in the morning (06:00-10:00) and evening (20:00-21:00) (Fig. 5). The peaks were mainly associated with traffic rush hour and low planetary boundary layer (PBL) depth before and after sunset. The relatively low concentration during the afternoon was probably due to the high PBL depth as shown by the mass concentration variations of $\mathrm{BC}$. The correlation between HOA and $\mathrm{BC}$ was high $\left(R^{2}=0.64\right.$, Fig. $7 \mathrm{f}$ and Table 2$)$, as a big fraction of $\mathrm{BC}$ has been thought to emit from traffic activities. The minimum of HOA concentration, which typically occurred during the afternoon or middle of the night, was still up to $\sim 2 \mu \mathrm{g} \mathrm{m}^{-3}$, suggesting a high background of HOA, which is likely due to the stagnant air conditions being unfavorable for the diffusion of aerosol. The size distribution of HOA showed a mode size of $\sim 200 \mathrm{~nm}$ (Fig. 3b), corresponding to the primary emitted aerosol behavior, and HOA could account for $\sim 25 \%$ of the mass of aerosols between 100 and $300 \mathrm{~nm}$ (Fig. 3c). The average concentration of HOA during winter 2013/2014 was $2.9 \mu \mathrm{g} \mathrm{m}^{-3}$, accounting for $9.8 \%$ of organics (Fig. 8a). This concentration was higher than that of summer 2012 in Lanzhou (2.9 vs. $1.8 \mu \mathrm{g} \mathrm{m}^{-3}$ ) likely due to the lower PBL during winter and stagnant air conditions. The mass contribution from HOA is similar to the result of winter 2013 at Beijing (9\%), which was also the lowest contributor to the total OA (Sun et al., 2013b; Zhang et al., 2014), probably due to more modern vehicles being used in recent years. 


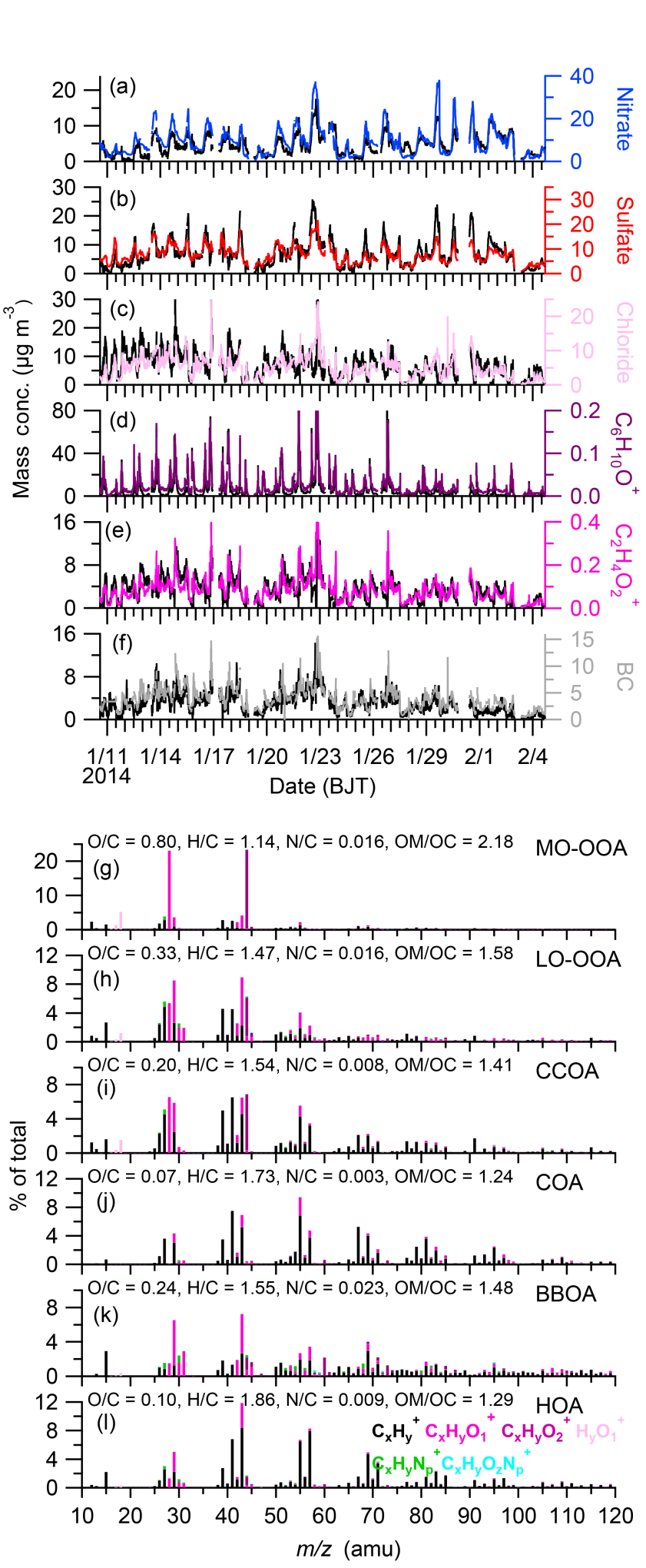

Figure 7. The PMF results of time series (a-f) and HR-MS (g-l) for each component. The temporal variations of different tracers are also present to support each component.

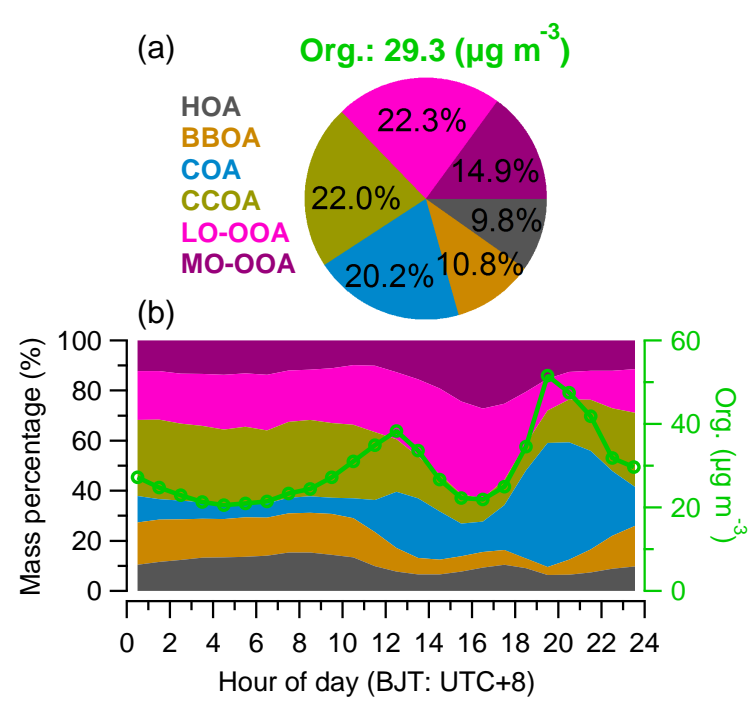

Figure 8. (a) The average mass concentration of organics and mass contributions of organic components to organics, and (b) the diurnal variations of organic components and organics.

\subsubsection{BBOA}

The BBOA component has been widely observed in USA and European countries during winter due to the traditional wood burning for residential heating (Alfarra et al., 2007). The BBOA component is thought to be less important in China because coal is the major fuel during winter. BBOA could be an important component in China during some special periods. For example, Zhang et al. (2015a) identified a BBOA factor in urban Nanjing, southeast of China, during harvest seasons of summer and autumn because of the burning of straw. The BBOA component has also been identified in some regions in China where the coal resource is scarce. For example, Du et al. (2015) separated a BBOA factor at a rural site on the northern Tibetan Plateau due to the wide usage of cow dung cake for heating in this region. The BBOA component has also been identified during winter in cities in southern China because of rich wood resources in these regions (He et al., 2011; Huang et al., 2011, 2013). To our knowledge, only three recent papers have reported the identification of a BBOA factor during winter using online measurement in an urban area of northern China (Elser et al., 2016; Hu et al., 2016; Sun et al., 2016). Although a high contribution of non-fossil carbonaceous aerosol was found (Zhang et al., 2015b) and the mass spectra of organic in other cities (such as Beijing) during winter also have significant contributions from $m / z 60$ and 73 (Sun et al., 2013b; Zhang et al., 2014), it is difficult to separate the BBOA using general PMF because of its similar temporal variation to CCOA, such as diurnal pattern (Fig. 4). BBOA contributions presented a clear periodic change (Fig. 1) and on average were high during nighttime and low during daytime (Fig. 5). This trend is consistent with conventional usage of biomass for heat- 
ing. The time series of BBOA was also closely correlated with $\mathrm{BC}$ and chloride (Table 2) due to significant emission of these species from biomass burning. The average mass concentration of BBOA was $3.2 \mu \mathrm{g} \mathrm{m}^{-3}$, on average contributing $10.8 \%$ of the total OA mass for the entire study (Fig. 8a), but it could reach up to $\sim 20 \%$ during night and go down to less than $5 \%$ during the afternoon (Fig. 8b). This average concentration was close to the results observed in southern Chinese cities such as Jiaxing $\left(\sim 3.9 \mu \mathrm{g} \mathrm{m}^{-3}\right.$; Huang et al., 2013), Kaiping ( $1.36 \mu \mathrm{g} \mathrm{m}^{-3}$; Huang et al., 2011), and Shenzhen $\left(\sim 5.2 \mu \mathrm{g} \mathrm{m}^{-3}\right.$; He et al., 2011).

The size distribution of BBOA peaked at $\sim 400 \mathrm{~nm}$, which is close to accumulation mode (Fig. 3b). This feature could be due to internal mixing or coagulation of particles. The $\mathrm{O} / \mathrm{C}$ ratio of $\mathrm{BBOA}$ is 0.24 , which is consistent with the primary BBOA feature (Ortega et al., 2013). The similar $\mathrm{O} / \mathrm{C}$ and the dominance of an accumulation mode in the size distribution of BBOA were also observed during winter in Fresno, a major city in the Central Valley of California, USA (Ge et al., 2012; Young et al., 2016).

\subsubsection{COA}

The COA component has been widely identified in urban AMS studies and observational results by other instruments recently, and it is regarded as an important source of OA in urban areas (Abdullahi et al., 2013, and references therein). The MS of COA in this study had a major contribution from $\mathrm{C}_{x} \mathrm{H}_{y}^{+}$ions $(81.6 \%)$ and also an important contribution from $\mathrm{C}_{x} \mathrm{H}_{y} \mathrm{O}_{1}^{+}$ions $(14.7 \%)$, similar to those in $\mathrm{HOA}(81.0 \%$ and $13.0 \%$; Fig. S9). In comparison with the HOA spectrum, COA had a higher $m / z 55$-to-57 ratio (2.0 vs. 0.8; Fig. 7), which has been postulated as a significant indicator for COA (Sun et al., 2011b; Mohr et al., 2012). In the V-shaped plot defined by Mohr et al. (2012), which uses $f 55$ vs. $f 57$ after subtracting the contributions from factors of OOA, CCOA, and BBOA (denoted as OOA_CCOA_BBOA_sub, i.e., $f 55_{\mathrm{OOA}} \mathrm{CCOA} \_\mathrm{BBOA} \_$sub and $f 57_{\mathrm{OOA}} \mathrm{CCOA} \_\mathrm{BBOA} \_$sub), the data can be clearly represented with ones during morning close to the HOA line and ones during mealtimes close to the COA line (Fig. S10). The MS of COA is highly similar to that of the summer 2012 observation $\left(R^{2}=0.76\right.$, slope $=0.99$, Fig. S11), which was found to resemble closely the COA MS from other locations (Xu et al., 2014). In fact, the COA components were found to be associated with heating of cooking oils rather than burning of meat/food itself, and indeed the COA mass spectra from cooking of different dishes were highly similar (He et al., 2010). The $\mathrm{O} / \mathrm{C}$ and $\mathrm{H} / \mathrm{C}$ ratios of $\mathrm{COA}$ were 0.07 and 1.73 , respectively, suggesting their feature as POA. This $\mathrm{O} / \mathrm{C}$ ratio was slightly lower $(0.07$ vs. 0.11 ), and the $\mathrm{H} / \mathrm{C}$ ratio was slightly higher than that of summer 2012 (1.73 vs. 1.69). The size distribution of COA also peaked between 100 and $200 \mathrm{~nm}$, similar to that of HOA (Fig. 3b). The diurnal variation of COA displayed two predominant peaks standing out at lunchtime (12:00-13:00) and
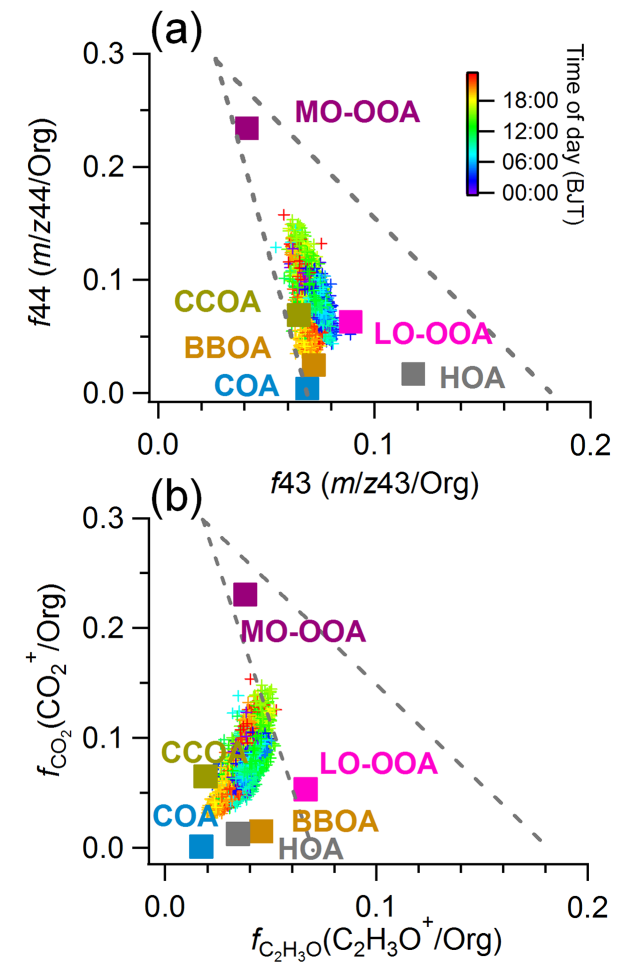

Figure 9. Scatterplots of (a) $f 44$ vs. $f 43$ and (b) $f \mathrm{CO}_{2}^{+}$vs. $f \mathrm{C}_{2} \mathrm{H}_{3} \mathrm{O}^{+}$. The cross dots correspond to measured $\mathrm{OA}$ data points and are colored by time of the day. The corresponding values of the six OA factors identified in this study are also shown.

dinnertime (19:00-20:00), respectively (Fig. 5), and a small breakfast peak $(\sim 8: 00)$. This pattern was consistent with that of summer 2012 (Fig. 4) which resulted from the consistent routine life during winter and summer. The enhanced COA concentration at dinnertime might be mainly due to the low PBL height and the activity of a formal meal with more attendants and longer time than that of lunch. The temporal variation correlated tightly with $\mathrm{C}_{6} \mathrm{H}_{10} \mathrm{O}^{+}\left(R^{2}=0.96\right.$, Fig. $\left.7 \mathrm{~d}\right)$, which has been reported as the high-resolution mass spectral markers for ambient COA (Sun et al., 2011b; Ge et al., 2012).

The average contribution of COA to organics was $20.2 \%$ ( $\sim 10-50 \%$; Fig. 8a) with an average mass concentration of $5.92 \mu \mathrm{g} \mathrm{m}^{-3}$, which was much higher than those of HOA and BBOA. This contribution is similar to those in Beijing during winter (average $19 \%$ of OA with a range of 16-30\%) (Sun et al., 2013b), Fresno ( $\sim 19 \%$ of OA; Ge et al., 2012), Barcelona (17\% of OA; Mohr et al., 2012), and Paris (11$17 \%$; Crippa et al., 2013). This high fraction indicates that COA is an important local source of OA in Lanzhou regardless of clear or hazy periods (Sect. 3.5).

\subsubsection{CCOA}

A CCOA component had been identified in this study with its MS similar to the OA from coal burning in a lab study 
(Dall'Osto et al., 2013). The MS of CCOA had high signals at $m / z 41,43,44,55,57,69,91$, and 115 (dominated by $\mathrm{C}_{x} \mathrm{H}_{y}^{+}$ions; Fig. 7i; Elser et al., 2016). $\mathrm{C}_{x} \mathrm{H}_{y}^{+}$ions in total account for $69.9 \%$ of CCOA MS, followed by $\mathrm{C}_{x} \mathrm{H}_{y} \mathrm{O}_{1}^{+}$ $(19.2 \%)$ and $\mathrm{C}_{x} \mathrm{H}_{y} \mathrm{O}_{2}^{+}(7.1 \%)$. The fractions of $\mathrm{C}_{x} \mathrm{H}_{y}^{+}$and $\mathrm{C}_{x} \mathrm{H}_{y} \mathrm{O}_{1}^{+}$were similar to those in HOA MS (Fig. S9), but the CCOA MS had high signal intensity at $\mathrm{m} / \mathrm{z} 44$ (mainly $\mathrm{CO}_{2}^{+}$), which is different from that of HOA (Fig. 7). This high $\mathrm{CO}_{2}^{+}$fraction was also observed in CCOA MS on Changdao Island in China during winter (Hu et al., 2013). Wang et al. (2015) suggested this high $\mathrm{CO}_{2}^{+}$signal is from the oxidative transformation of the pyrolysis products during coal burning. Zhang et al. (2008) reported that $48-68 \%$ of particulate organic matter from coal combustion aerosol is found in the form of organic acids. The $\mathrm{O} / \mathrm{C}$ ratio is thus higher than that of HOA (0.20 vs. 0.10$)$ with a lower $\mathrm{H} / \mathrm{C}$ ratio (1.54 vs. 1.86). The CCOA is also located in a lower left position in the triangle plot defined by $\mathrm{Ng}$ et al. (2010) (Fig. 9a). These features indicate CCOA is a POA factor but is a little more oxygenated than HOA. The time-dependent concentrations of CCOA correlated with BC $\left(R^{2}=0.59\right)$ and chloride $\left(R^{2}=0.49\right)$, which also correlated well with HOA and BBOA (Table 2). Note that, despite the similar temporal variations between $\mathrm{BBOA}$ and $\mathrm{CCOA}$, the significant differences between their MS (in particular, $m / z$ 91) suggested their different origins. In addition, high PAH signals have been observed in the CCOA MS (Sun et al., 2016), and this is consistent with previous results that the coal combustion could be a dominate source of PAHs in China (Okuda et al., 2006). The CCOA mass loading remained high from 20:00 to 10:00, slowly decreased to a minimum at 16:00, and then increased from 16:00 to 20:00 (Fig. 5). This diurnal pattern was similar to that of BBOA, which was all mainly emitted from heating. The slower decreasing rate during morning and increasing rate during the late afternoon for CCOA as compared to those of BBOA could be related to the wide usage of coal, such as cooking and power plants. In our summer 2012 observation, we also observed OA signals from coal combustion which suggest persistent emission during the whole year in Lanzhou. The size distribution of CCOA peaked $\sim 450 \mathrm{~nm}$ (Fig. 3b), similar to that of BBOA.

The average CCOA mass concentration was $6.4 \mu \mathrm{g} \mathrm{m}^{-3}$, accounting for $22.0 \%$ of total OA mass (Fig. 8a). The mass fraction of CCOA could reach up to $\sim 30 \%$ of OA at night and decreased to $3 \%$ during the afternoon (Fig. $8 \mathrm{~b}$ ). This indicates that CCOA was an important OA component similar to that in Beijing OA (15-55\%; Zhang et al., 2014; Elser et al., 2016), but its mass fraction of $\mathrm{PM}_{2.5}(\sim 9 \%)$ was at the low end of the values observed at Beijing and Xi' an (9-21\%) (Huang et al., 2014).

\subsubsection{LO-OOA and MO-OOA}

Two or more OOA components are commonly separated by PMF in urban areas, which correspond to fresh SOA and aged SOA (Jimenez et al., 2009), and the MS of SOA factors all have predominant contributions at $m / z 43$ and 44 . The MS of fresher SOA such as LO-OOA has higher contribution at $m / z 43$ (mainly $\mathrm{C}_{2} \mathrm{H}_{3} \mathrm{O}^{+}$, accounting for $74 \%$ of $m / z 43$ in this study), while aged SOA such as MO-OOA has higher signal at $m / z 44$ (mainly $\mathrm{CO}_{2}^{+}$, accounting for $99 \%$ of $m / z 44$ in this study). The contribution of $\mathrm{C}_{x} \mathrm{H}_{y} \mathrm{O}_{1}^{+}$in LO-OOA was $36.8 \%$, followed by $\mathrm{C}_{x} \mathrm{H}_{y}^{+}(48.0 \%), \mathrm{C}_{x} \mathrm{H}_{y} \mathrm{O}_{2}^{+}$ $(10.3 \%), \mathrm{H}_{y} \mathrm{O}_{1}^{+}(1.6 \%), \mathrm{C}_{x} \mathrm{H}_{y} \mathrm{~N}_{p}^{+}(2.8 \%)$, and $\mathrm{C}_{x} \mathrm{H}_{y} \mathrm{O}_{z} \mathrm{~N}_{p}^{+}$ $(0.5 \%$; Fig. S9). The $\mathrm{O} / \mathrm{C}$ ratio of LO-OOA was 0.33 and $\mathrm{H} / \mathrm{C}$ was 1.47 , consistent with fresh SOA. The MS of MO-OOA comprised $25.3 \% \mathrm{C}_{x} \mathrm{H}_{y} \mathrm{O}_{2}^{+}, 35.7 \% \mathrm{C}_{x} \mathrm{H}_{y} \mathrm{O}_{1}^{+}$, $30.1 \% \mathrm{C}_{x} \mathrm{H}_{y}^{+}, 6.7 \% \mathrm{H}_{x} \mathrm{O}_{1}^{+}, 1.8 \%$ of $\mathrm{C}_{x} \mathrm{H}_{y} \mathrm{~N}_{p}^{+}$, and $0.4 \%$ of $\mathrm{C}_{x} \mathrm{H}_{y} \mathrm{O}_{z} \mathrm{~N}_{p}^{+}$(Fig. S9). The $\mathrm{O} / \mathrm{C}$ and $\mathrm{H} / \mathrm{C}$ ratios of $\mathrm{MO}-$ OOA were 0.80 and 1.14 , respectively. These results indicate that the atmospheric oxidation capacity during winter was still somewhat strong. The positions of LO-OOA and MOOOA in the triangle plot of $f \mathrm{CO}_{2}^{+}$vs. $f \mathrm{C}_{2} \mathrm{H}_{3} \mathrm{O}^{+}$are situated in the space of the triangle plot with $\mathrm{MO}-\mathrm{OOA}$ at the upper left corner (Fig. 9b) and LO-OOA at the lower right space, suggesting the different oxidation degree of OOA factors. The MS of LO-OOA and MO-OOA were similar to those of summer $2012\left(R^{2}=0.95\right.$ for MO-OOA and $R^{2}=0.80$ for LO-OOA, Fig. S11). Note that the $\mathrm{C}_{x} \mathrm{H}_{y}^{+}$ions in LO-OOA were mainly from $m / z 39,41,91$, and 115 (Fig. 7h), which were also found to be enriched in coal combustion organic aerosols. This feature is similar to that of summer 2012, potentially suggesting that part of LO-OOA was from further oxidation of CCOA.

The temporal variations of LO-OOA and MO-OOA were highly correlated with secondary inorganic species: LOOOA vs. sulfate $\left(R^{2}=0.71\right)$ and MO-OOA vs. nitrate ( $R^{2}=0.71$; Fig. $7 \mathrm{a}$ and b, Table 2 ). These patterns are somewhat contradictory to previous AMS findings that LO-OOA typically correlates better with nitrate due to their similar semivolatile characteristics, while MO-OOA tends to correlate better with sulfate as they are both low-volatility species. These correlations were indeed observed during the summer study of 2012 (Xu et al., 2014). The behavior of the two OOA factors during this study were likely due to the low air temperature and low RH conditions, which favored nitrate formation primarily through photochemical reactions. This phenomenon was also observed in wintertime in Beijing (Sun et al., 2013b).

The diurnal variation profiles of LO-OOA and MO-OOA all showed one bump, with the LO-OOA peaking between 11:00 and 14:00 and MO-OOA peaking between 12:00 and 18:00, suggesting the importance of photochemical processes for both OOA factors. The size distribution of the OOA (LO-OOA + MO-OOA) had a mode size of $\sim 550 \mathrm{~nm}$ 

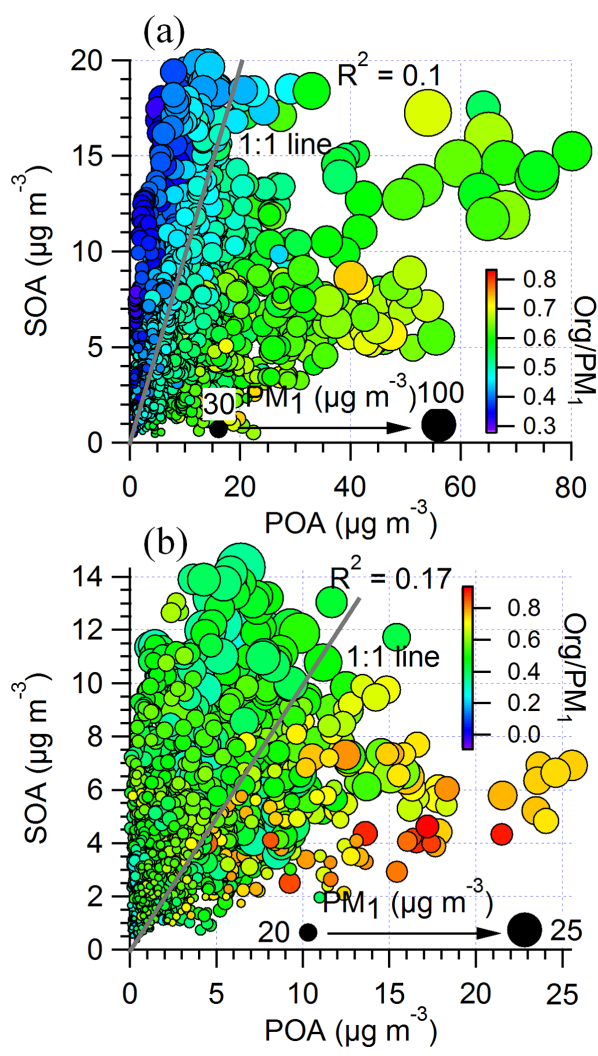

Figure 10. The scatterplot of SOA and POA colored by the ratio of organic $(\mathrm{Org}) / \mathrm{PM}_{1}$ and sized by the mass concentration of $\mathrm{PM}_{1}$ for (a) winter 2013/2014 and (b) summer 2012.

(Fig. 3b) reflecting the feature as SOA. This size mode is slightly bigger than those of OOA in other studies such as Fresno $(460 \mathrm{~nm})$ and Lanzhou summer $2012(\sim 450 \mathrm{~nm})$ likely due to the high concentration of gas precursors and longer life cycle of aerosol during winter.

The mass concentrations of LO-OOA and MO-OOA were 6.5 and $4.4 \mu \mathrm{g} \mathrm{m}^{-3}$ with mass contributions of 22.3 and $14.9 \%$ to OA, respectively (Fig. 8a). These contributions were lower than those during summer 2012 in Lanzhou ( $27 \%$ for LO-OOA and $32 \%$ for MO-OOA) especially for MOOOA, likely due to the relatively weak solar radiation during winter and more primary sources in winter. The diurnal total contribution of OOA (LO-OOA + MO-OOA) varied between 20 and $60 \%$ (Fig. 8b), suggesting the importance of SOA in the air pollution throughout the day at Lanzhou.

\subsection{Primary and secondary $\mathrm{OA}$}

As shown in Fig. 2b, the mass fraction of organics increased with the increase of $\mathrm{PM}_{1}$ concentration, so it is important to know the relative contributions of primary and secondary OA components during the pollution periods. Fig. 10a shows the scatterplot of SOA (= LO-OOA + MO-OOA $)$ and POA $(=\mathrm{HOA}+\mathrm{BBOA}+\mathrm{COA}+\mathrm{CCOA})$ during this study. Over-
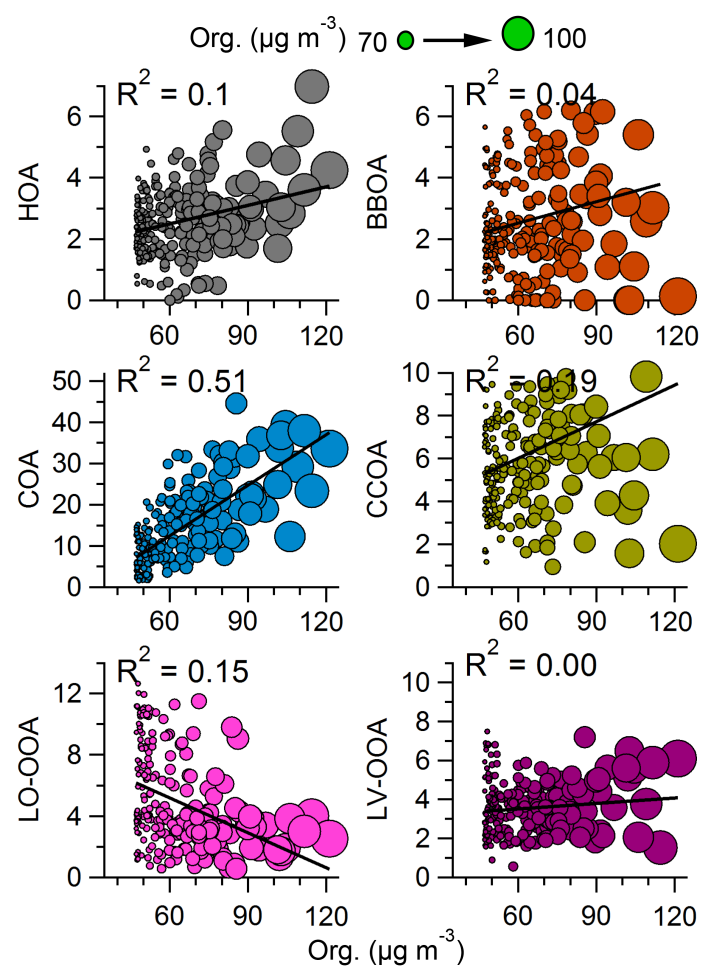

Figure 11. The scatterplots of each organic component $\left(\mu \mathrm{g} \mathrm{m}^{-3}\right)$ vs. organics during haze periods (definite as organics $>43 \mu \mathrm{g} \mathrm{m}^{-3}$; Org_avg $+1 \sigma)$.

all, the SOA and POA correlate weakly, but when POA concentrations were less than $\sim 15 \mu \mathrm{g} \mathrm{m}^{-3}$ and the $\mathrm{OA}$ and $\mathrm{PM}_{1}$ mass fractions were less than 0.5 (data points with green/blue colors), they had a relatively tight correlation $\left(R^{2}=0.2\right)$. When POA concentrations and organic $/ \mathrm{PM}_{1}$ fractions were large, POA and SOA showed almost no correlation, indicating the importance of POA in the severe aerosol pollution in Lanzhou during winter. This is different than the observation from summer 2012, during which SOA had a stable contribution to $\mathrm{PM}_{1}$ (Fig. 10b), due to more complex POA sources and larger contributions from these sources to $\mathrm{PM}_{1}$ mass loading during winter than summer. This is even more evident when comparing each POA factor with OA (Fig. 11). The COA had the biggest contribution to the increased organics, accounting for $51 \%$ of the increase of organics, followed by CCOA (19\%). The components of HOA and BBOA also had positive contributions to the increase of $\mathrm{PM}_{1}$ mass. However, both OOA components had negative slopes, with organics with LO-OOA being the major one. The phenomenon of POA dominating during haze periods is different from the results in other cities in China (Huang et al., 2014). For example, Elser et al. (2016) found significantly increased contribution from SOA and secondary inorganic aerosol during haze periods in winter 2013/2014 in Xi' an and Beijing. This is likely due to the higher RH values in eastern China, which is more favorable for the aqueous-phase production of SOA. 


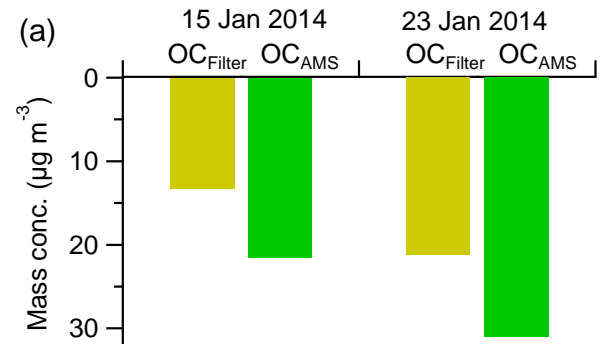

(b)

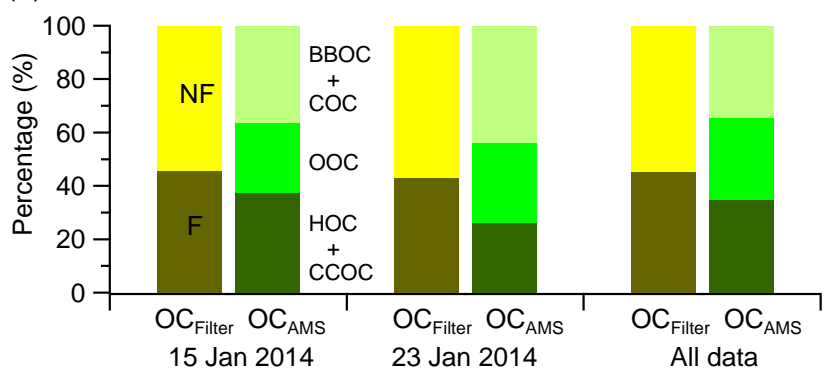

Figure 12. The comparisons of (a) $\mathrm{OC}$ concentration measured by filter sample $\left(\mathrm{OC}_{\mathrm{Filter}}\right)$ and $\mathrm{AMS}\left(\mathrm{OC}_{\mathrm{AMS}}\right)$ on 15 and 23 January 2014 and (b) the non-fossil (NF) and fossil (F) carbon fraction measured by ${ }^{14} \mathrm{C}$ and $\mathrm{OC}$ components in AMS.

Indeed, Sun et al. (2013a) observed significant increase of secondary inorganic aerosol during high-RH periods in Beijing.

The average contribution of POA to organics decreased from 63.0 to $39.3 \%$ during the Chinese New Year festival of 2014 (Fig. 1) due to the reduced primary aerosol sources (many restaurants were closed during the holiday of the Chinese New Year) such as HOA (9.8 to $3.3 \%$ ), COA (20.2 to $11.6 \%$ ), $\mathrm{CCOA}$ (22.0 to $15.4 \%$ ), and BBOA (10.8 to $9.0 \%$ ). This is an indication that control of cooking activities and traffic emissions in this residential area may be effective strategies for air quality improvement during winter.

\subsection{Fossil and non-fossil OC}

OC measured by an OC-EC analyzer on two filters $\left(\mathrm{OC}_{\text {filter }}\right)$ and corresponding AMS ( $\left.\mathrm{OC}_{\mathrm{AMS}}\right)$ online-measured results are shown in Fig. 12a. The average ratio of $\mathrm{OC}_{\mathrm{AMS}} / \mathrm{OC}_{\text {filter }}$ was $\sim 1.5$ for these two filters, although the smaller size cut for AMS than the filter sampler $\left(\mathrm{PM}_{1}\right.$ vs. $\left.\mathrm{PM}_{2.5}\right)$. This is likely due to the analytical uncertainties of different instruments ( 30 for AMS and $20 \%$ for $\mathrm{OC}_{\text {filter }}$ ), which were also observed in other studies (Zotter et al., 2014), and negative artifacts for the filter samples. The data from the ${ }^{14} \mathrm{C}$ measurement for the filter samples are listed in Table $\mathrm{S} 1$ in the Supplement. The total average of $f_{\mathrm{NF}}$ in these four filters was $55 \pm 3 \%$, with 54 and $57 \%$ for filters during 15 and 23 January, respectively. In comparison with other studies, the average $f_{\mathrm{NF}}$ value in this study was lower than those in $\mathrm{Xi}$ 'an $(63 \%)$ and Guangzhou (65\%), higher than that in Beijing

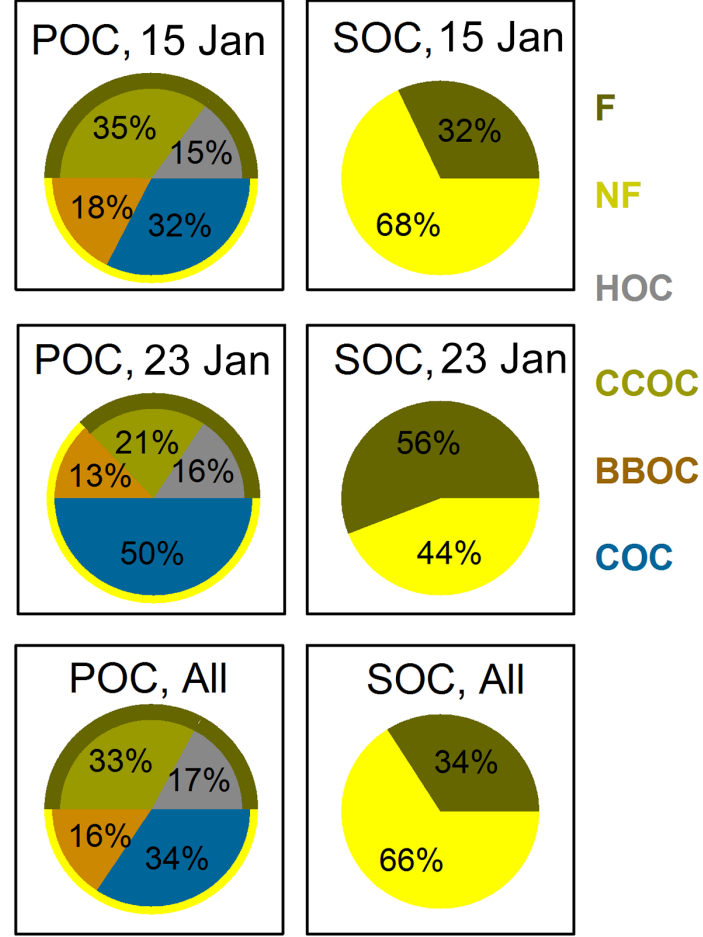

Figure 13. The NF and F carbon fraction in POC and SOC during 15 and 23 January and all data of AMS.

(42\%), and similar to those in Shanghai (51\%) during winter 2012/2013 (Zhang et al., 2015b). Combining with the $f_{\mathrm{NF}}$ value (the total average of $f_{\mathrm{NF}}$ for the total average AMS results) and the contributions of fossil primary organic carbon (F POC) (HOC and CCOC) and NF POC (BBOC and COC), the $f_{\mathrm{F}}$ and $f_{\mathrm{NF}}$ for secondary organic carbon (SOC) could be obtained (Fig. 12b). The average $f_{\mathrm{F}}$ and $f_{\mathrm{NF}}$ for POC and SOC are summarized in Fig. 13. The $f_{\mathrm{F}}$ and $f_{\mathrm{NF}}$ for POC during 15 January were 50 and $50 \%$, while for SOC they were 32 and $68 \%$, respectively. The $f_{\mathrm{F}}$ and $f_{\mathrm{NF}}$ for POC during 23 January were 37 and $63 \%$, while for SOC they were 56 and $44 \%$, respectively. For all AMS data, the $f_{\mathrm{F}}$ and $f_{\mathrm{NF}}$ in POC were $50 \%$ and $50 \%$, while for SOC they were $34 \pm 10 \%$ and $66 \pm 10 \%$, respectively. The F POC during 15 and 23 January comprised 15 and $16 \mathrm{HOC}$ and 35 and $21 \%$ CCOC, respectively, and NF POC comprised 18 and $13 \mathrm{BBOC}$ and 32 and $50 \%$ COC, respectively. For all AMS data, the F POC comprised $17 \mathrm{HOC}$ and $33 \% \mathrm{CCOC}$, and NF POC comprised 16 BBOC and $34 \%$ COC.

\subsection{Evolution of $\mathrm{OA}$ and relationship between odd oxygen and SOA}

The evolution of OA chemical composition upon aging has been an important subject which is used to understand the formation of SOA. The methods to characterize this evolution include the application of several specific diagrams, 

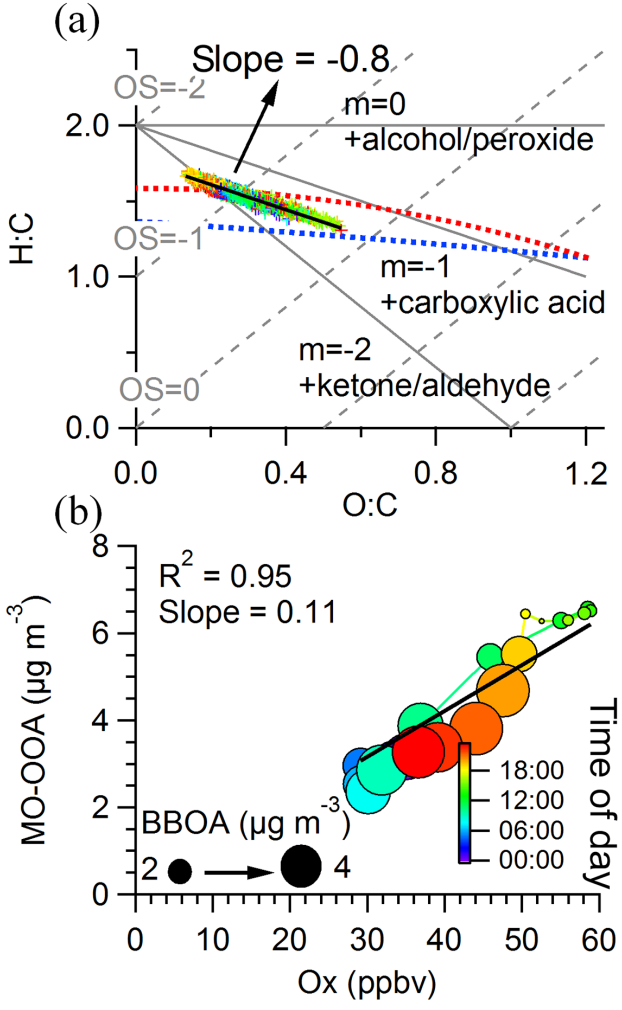

Figure 14. (a) Van Krevelen diagram for OA and (b) scatterplot of MO-OOA vs. $\mathrm{O}_{x}$ (the sum of $\mathrm{O}_{3}$ and $\mathrm{NO}_{2}$ ) with linear fit and colored by time of day.

such as the AMS triangle plot ( $f 44$ vs. $f 43$ or $f \mathrm{CO}_{2}^{+}$vs. $f \mathrm{C}_{2} \mathrm{H}_{3} \mathrm{O}^{+} ; \mathrm{Ng}$ et al., 2010) and Van Krevelen plot $(\mathrm{H}: \mathrm{C}$ vs. O:C; Heald et al., 2010). In the plot of $f 44$ vs. $f 43$ of this study (Fig. 9a), the data are distributed in a narrow space and move up vertically in the triangle space, suggesting significant increasing at $f 44$. The data from the low (nighttime) to the high (afternoon) $f 44$ value corresponded to the evolution of the photo radiation intensity, suggesting photochemical processes. In the plot of $f \mathrm{CO}_{2}^{+}$vs. $f \mathrm{C}_{2} \mathrm{H}_{3} \mathrm{O}^{+}$ (Fig. 9b), most of the data moved out of triangle space because of the high contribution of $\mathrm{C}_{3} \mathrm{H}_{7}^{+}$at $m / z 43$, especially for data during nighttime. $f \mathrm{CO}_{2}^{+}$and $f \mathrm{C}_{2} \mathrm{H}_{3} \mathrm{O}^{+}$both increased before noontime; after that $f \mathrm{C}_{2} \mathrm{H}_{3} \mathrm{O}^{+}$stopped at $\sim 0.06$, and $f \mathrm{CO}_{2}^{+}$kept increasing, likely suggesting the evolution of LO-OOA to MO-OOA. In comparison to the results in summer 2012, the data in winter were more concentrated in the triangle space, suggesting air masses with similar source contribution during winter. The winter data in the Van Krevelen diagram follows a slope of -0.8 (Fig. 14a), which suggests that SOA formation chemistry was a combination of carboxylic acid and alcohol/peroxide formation $(-1$ to -0.5$)$. This slope is higher than that observed at Changdao (-0.6, rural site) in China during winter, suggesting the less-oxidized state of our data.
In order to understand the possible sources of oxygenated $\mathrm{OA}$, we also compared the diurnal variations between MO-OOA and $\mathrm{O}_{x}$ (Fig. 14b). Both $\mathrm{O}_{x}$ and OOA are products of photochemical reactions, and the comparison between $\mathrm{O}_{x}$ and OOA can offer insight into the formation of $\mathrm{OA}$ due to the dependence of the ratio on the volatile organic carbon (VOC) species (Herndon et al., 2008), assuming aqueous processing and nighttime oxidation for OOA were less important, such as during this study due to the low RH. High SOA vs. $\mathrm{O}_{x}$ slopes were observed (larger than $0.12 \mu \mathrm{g} \mathrm{m}^{-3} \mathrm{ppb}^{-1}$ ) where aromatic VOC dominated the photochemical processing, while low slopes $\left(\sim 0.03 \mu \mathrm{g} \mathrm{m}^{-3} \mathrm{ppb}^{-1}\right)$ were observed where alkene VOCs dominated the photochemical processing (Wood et al., 2010; Hayes et al., 2013). Figure 14b shows the scatterplot between $\mathrm{O}_{x}$ and MO-OOA and sized by the mass concentration of BBOA. $\mathrm{O}_{x}$ and MO-OOA showed a tight correlation $\left(R^{2}=0.95\right)$ with a slope of $0.11 \mu \mathrm{g} \mathrm{m}^{-3} \mathrm{ppb}^{-1}$. This result is similar to that found in Beijing during wintertime, which has suggested that semivolatile VOCs (e.g., PAHs) could be the primary precursor of OOA (Hu et al., 2016). Several studies have suggested that aromatic VOC is dominant among VOCs in northern China (Zhang et al., 2015c) and can be an important contribution for SOA production (Liu et al., 2012). We also did a correlation between LO-OOA and $\mathrm{O}_{x}$, and found different synchronization of LO-OOA and $\mathrm{O}_{x}$ (Fig. S12). It seems LO-OOA varied 2-3 h earlier than $\mathrm{O}_{x}$, likely suggesting another origination for LO-OOA such as down-mixing of mixing-layer aerosol, which is a popular phenomenon in the mountain valley city (Chen et al., 2009).

\section{Conclusions}

In order to understand the sources and chemical processes of the air pollution during winter in Lanzhou, a field study was conducted at an urban site of Lanzhou during 10 January-February 42014 using a suit of online instruments. The results show that the average mass concentration of $\mathrm{PM}_{1}\left(\mathrm{NR}-\mathrm{PM}_{1}+\mathrm{BC}\right.$ ) was $57.3 \mu \mathrm{g} \mathrm{m}^{-3}$ (ranging from 2.1 to $229.7 \mu \mathrm{g} \mathrm{m}^{-3}$ for hourly averages), with 51.2 organics, 16.5 nitrate, 12.5 sulfate, 10.3 ammonium, $6.4 \mathrm{BC}$, and $3.0 \%$ chloride. This mass concentration was about 2 times higher than that during summer 2012 in Lanzhou; however, the mass loading levels and chemical compositions were similar to those observed in Beijing during winter. The mass concentration of nitrate and organics increased with the increase of $\mathrm{PM}_{1}$ loading, while sulfate decreased, indicating the importance of OA and nitrate during severe air pollution. The size distributions of all the species displayed a moderate size at $400-500 \mathrm{~nm}$, suggesting that aerosol particles were largely internally mixed during winter. All species presented significant diurnal variations. BC had two peaks at 10:00-12:00 and 20:00-22:00. Further analysis indicated that the first peak resulted from the contribution of multiple combustion sources 
and could be related to the variations of the boundary layer heights during morning, which accumulated the air pollutants from early morning until the breakup at around noontime (such influences should be further verified in the future with simultaneous measurements from boundary layer heights). The evening peak of $\mathrm{BC}$ was related to human activities such as traffic and coal combustion coupled with the shallow PBL. OA presented two peaks corresponding to lunch and dinnertime, suggesting cooking to be an important source. Sulfate peaked around noontime (11:00-14:00), indicating the importance of photochemical processes. Nitrate presented an afternoon peak (12:00-16:00), which indicated the photochemical processing of $\mathrm{NO}_{x}$. The diurnal pattern of nitrate during wintertime was significantly different from that during summer 2012, which was thought mainly to be from the mixing down of aloft residual layer. PMF analysis of organic mass spectrum with the ME-2 engine identified six organic aerosol sources: i.e., HOA, BBOA, COA, CCOA, LOOOA, and MO-OOA. POA - which includes HOA, BBOA, COA, and CCOA - accounted for $63 \%$ of OA mass and showed an increased in concentration with the increase of $\mathrm{PM}_{1}$ loading. This is an indication that POA emission was one of the main reasons for the occurrence of heavy air pollution episodes. The temporal profile of MO-OOA was tightly correlated with that of nitrate, while those of LO-OOA were tightly correlated with sulfate. This observation was different than those observed during other studies and during summer at Lanzhou, indicating the importance of photochemistry for nitrate during winter in Lanzhou due to cold air temperature and low-RH conditions. ${ }^{14} \mathrm{C}$ analysis of OOC indicated that $66 \pm 10 \%$ of the SOC was formed from non-fossil sources.

\section{Data availability}

The processed AMS data and meteorological data in this study are available upon request from the corresponding author. Air quality data have been obtained from public archives (see main text for details).

\section{The Supplement related to this article is available online at doi:10.5194/acp-16-14937-2016-supplement.}

Acknowledgements. The authors thank their colleagues for continuing support and discussion. This research was supported by grants from the Chinese Academy of Sciences Hundred Talents Program, the Key Laboratory of Cryospheric Sciences Scientific Research Foundation (SKLCS-ZZ-2015-01), the National Natural Science Foundation of China Science Fund for Creative Research Groups (41121001, 21407079, 91544220), and the Chinese Academy of Sciences Key Research Program (KJZD-EW-G03).

Edited by: E. Browne

Reviewed by: two anonymous referees

\section{References}

Abdullahi, K. L., Delgado-Saborit, J. M., and Harrison, R. M.: Emissions and indoor concentrations of particulate matter and its specific chemical components from cooking: A review, Atmos. Environ., 71, 260-294, doi:10.1016/j.atmosenv.2013.01.061,2013.

Agrios, K., Salazar, G. A., Zhang, Y. L., Uglietti, C., Battaglia, M., Luginbühl, M., Ciobanu, V. G., Vonwiller, M., and Szidat, S.: Online coupling of pure $\mathrm{O}_{2}$ thermo-optical methods ${ }^{14} \mathrm{C}$ AMS for source apportionment of carbonaceous aerosols study, Nucl. Instrum. Meth. Phys. Res. B., 361, 288-293, doi:10.1016/j.nimb.2015.06.008, 2015.

Aiken, A. C., DeCarlo, P. F., Kroll, J. H., Worsnop, D. R., Huffman, J. A., Docherty, K. S., Ulbrich, I. M., Mohr, C., Kimmel, J. R., Sueper, D., Sun, Y., Zhang, Q., Trimborn, A., Northway, M., Ziemann, P. J., Canagaratna, M. R., Onasch, T. B., Alfarra, M. R., Prevot, A. S. H., Dommen, J., Duplissy, J., Metzger, A., Baltensperger, U., and Jimenez, J. L.: O / C and OM/OC ratios of primary, secondary, and ambient organic aerosols with highresolution time-of-flight aerosol mass spectrometry, Environ. Sci. Technol., 42, 4478-4485, doi:10.1021/es703009q, 2008.

Alfarra, M. R., Prevot, A. S. H., Szidat, S., Sandradewi, J., Weimer, S., Lanz, V. A., Schreiber, D., Mohr, M., and Baltensperger, U.: Identification of the Mass Spectral Signature of Organic Aerosols from Wood Burning Emissions, Environ. Sci. Technol., 41, 5770-5777, doi:10.1021/es062289b, 2007.

Beekmann, M., Prévôt, A. S. H., Drewnick, F., Sciare, J., Pandis, S. N., Denier van der Gon, H. A. C., Crippa, M., Freutel, F., Poulain, L., Ghersi, V., Rodriguez, E., Beirle, S., Zotter, P., von der Weiden-Reinmüller, S.-L., Bressi, M., Fountoukis, C., Petetin, H., Szidat, S., Schneider, J., Rosso, A., El Haddad, I., Megaritis, A., Zhang, Q. J., Michoud, V., Slowik, J. G., Moukhtar, S., Kolmonen, P., Stohl, A., Eckhardt, S., Borbon, A., Gros, V., Marchand, N., Jaffrezo, J. L., Schwarzenboeck, A., Colomb, A., Wiedensohler, A., Borrmann, S., Lawrence, M., Baklanov, A., and Baltensperger, U.: In situ, satellite measurement and model evidence on the dominant regional contribution to fine particulate matter levels in the Paris megacity, Atmos. Chem. Phys., 15, 9577-9591, doi:10.5194/acp-15-9577-2015, 2015.

Bi, J., Huang, J., Hu, Z., Holben, B. N., and Guo, Z.: Investigating the aerosol optical and radiative characteristics of heavy haze episodes in Beijing during January of 2013, J. Geophys. Res., 119, 9884-9900, doi:10.1002/2014JD021757, 2014.

Bond, T. and Bergstrom, R.: Light absorption by carbonaceous particles: An investigative review, Aerosol. Sci. Tech., 40, 27-67, doi:10.1080/02786820500421521, 2006.

Canagaratna, M. R., Jayne, J. T., Jimenez, J. L., Allan, J. D., Alfarra, M. R., Zhang, Q., Onasch, T. B., Drewnick, F., Coe, H., Middlebrook, A., Delia, A., Williams, L. R., Trimborn, A. M., Northway, M. J., DeCarlo, P. F., Kolb, C. E., Davidovits, P., and Worsnop, D. R.: Chemical and microphysical characterization of ambient aerosols with the aerodyne aerosol mass spectrometer, Mass Spectrom. Rev., 26, 185-222, doi:10.1002/mas.20115, 2007.

Canagaratna, M. R., Jimenez, J. L., Kroll, J. H., Chen, Q., Kessler, S. H., Massoli, P., Hildebrandt Ruiz, L., Fortner, E., Williams, L. R., Wilson, K. R., Surratt, J. D., Donahue, N. M., Jayne, J. T., and Worsnop, D. R.: Elemental ratio measurements of organic compounds using aerosol mass spectrometry: characterization, 
improved calibration, and implications, Atmos. Chem. Phys., 15, 253-272, doi:10.5194/acp-15-253-2015, 2015.

Canonaco, F., Crippa, M., Slowik, J. G., Baltensperger, U., and Prévôt, A. S. H.: SoFi, an IGOR-based interface for the efficient use of the generalized multilinear engine (ME-2) for the source apportionment: ME-2 application to aerosol mass spectrometer data, Atmos. Meas. Tech., 6, 3649-3661, doi:10.5194/amt6-3649-2013, 2013.

Cao, C., Jiang, W., Wang, B., Fang, J., Lang, J., Tian, G., Jiang, J., and Zhu, T. F.: Inhalable Microorganisms in Beijing's PM2.5 and PM10 Pollutants during a Severe Smog Event, Environ. Sci. Technol., 48, 1499-1507, doi:10.1021/es4048472, 2014.

Carlton, A. G., Bhave, P. V., Napelenok, S. L., Edney, E. O., Sarwar, G., Pinder, R. W., Pouliot, G. A., and Houyoux, M.: Model Representation of Secondary Organic Aerosol in Cmaqv4.7, Environ. Sci. Technol., 44, 8553-8560, doi:10.1021/es100636q, 2010.

Chan, C. K. and Yao, X.: Air pollution in mega cities in China, Atmos. Environ., 42, 1-42, doi:10.1016/j.atmosenv.2007.09.003, 2008.

Chen, Y., Zhao, C., Zhang, Q., Deng, Z., Huang, M., and Ma, X.: Aircraft study of Mountain Chimney Effect of Beijing, China, J. Geophys. Res., 114, D08306, 10.1029/2008JD010610, 2009.

Crippa, M., Canonaco, F., Lanz, V. A., Äijälä, M., Allan, J. D., Carbone, S., Capes, G., Ceburnis, D., Dall'Osto, M., Day, D. A., DeCarlo, P. F., Ehn, M., Eriksson, A., Freney, E., Hildebrandt Ruiz, L., Hillamo, R., Jimenez, J. L., Junninen, H., KiendlerScharr, A., Kortelainen, A. M., Kulmala, M., Laaksonen, A., Mensah, A. A., Mohr, C., Nemitz, E., O’Dowd, C., Ovadnevaite, J., Pandis, S. N., Petäjä, T., Poulain, L., Saarikoski, S., Sellegri, K., Swietlicki, E., Tiitta, P., Worsnop, D. R., Baltensperger, U., and Prévôt, A. S. H.: Organic aerosol components derived from 25 AMS data sets across Europe using a consistent ME-2 based source apportionment approach, Atmos. Chem. Phys., 14, 61596176, doi:10.5194/acp-14-6159-2014, 2014.

Crippa, M., DeCarlo, P. F., Slowik, J. G., Mohr, C., Heringa, M. F., Chirico, R., Poulain, L., Freutel, F., Sciare, J., Cozic, J., Di Marco, C. F., Elsasser, M., Nicolas, J. B., Marchand, N., Abidi, E., Wiedensohler, A., Drewnick, F., Schneider, J., Borrmann, S., Nemitz, E., Zimmermann, R., Jaffrezo, J. L., Prévôt, A. S. H., and Baltensperger, U.: Wintertime aerosol chemical composition and source apportionment of the organic fraction in the metropolitan area of paris, Atmos. Chem. Phys., 13, 961-981, doi:10.5194/acp-13-961-2013, 2013.

Dall'Osto, M., Ovadnevaite, J., Ceburnis, D., Martin, D., Healy, R. M., O'Connor, I. P., Kourtchev, I., Sodeau, J. R., Wenger, J. C., and O'Dowd, C.: Characterization of urban aerosol in Cork city (Ireland) using aerosol mass spectrometry, Atmos. Chem. Phys., 13, 4997-5015, doi:10.5194/acp-13-4997-2013, 2013.

DeCarlo, P. F., Kimmel, J. R., Trimborn, A., Northway, M. J., Jayne, J. T., Aiken, A. C., Gonin, M., Fuhrer, K., Horvath, T., Docherty, K. S., Worsnop, D. R., and Jimenez, J. L.: Field-Deployable, High-Resolution, Time-of-Flight Aerosol Mass Spectrometer, Anal. Chem., 78, 8281-8289, doi:10.1021/ac061249n, 2006.

Du, W., Sun, Y. L., Xu, Y. S., Jiang, Q., Wang, Q. Q., Yang, W., Wang, F., Bai, Z. P., Zhao, X. D., and Yang, Y. C.: Chemical characterization of submicron aerosol and particle growth events at a national background site ( 3295 ma.s.1.) on the Tibetan Plateau, Atmos. Chem. Phys., 15, 10811-10824, doi:10.5194/acp-1510811-2015, 2015.
Dzepina, K., Arey, J., Marr, L. C., Worsnop, D. R., Salcedo, D., Zhang, Q., Onasch, T. B., Molina, L. T., Molina, M. J., and Jimenez, J. L.: Detection of Particle-Phase Polycyclic Aromatic Hydrocarbons in Mexico City Using an Aerosol Mass Spectrometer, Int. J. Mass Spectrom., 263, 152-170, doi:10.1016/j.ijms.2007.01.010, 2007.

Elser, M., Huang, R.-J., Wolf, R., Slowik, J. G., Wang, Q., Canonaco, F., Li, G., Bozzetti, C., Daellenbach, K. R., Huang, Y., Zhang, R., Li, Z., Cao, J., Baltensperger, U., El-Haddad, I., and Prévôt, A. S. H.: New insights into PM2.5 chemical composition and sources in two major cities in China during extreme haze events using aerosol mass spectrometry, Atmos. Chem. Phys., 16, 3207-3225, doi:10.5194/acp-16-3207-2016, 2016.

Ge, X., Setyan, A., Sun, Y., and Zhang, Q.: Primary and secondary organic aerosols in Fresno, California during wintertime: Results from high resolution aerosol mass spectrometry, J. Geophys. Res., 117, D19301, doi:10.1029/2012jd018026, 2012.

Hayes, P. L., Ortega, A. M., Cubison, M. J., Froyd, K. D., Zhao, Y., Cliff, S. S., Hu, W. W., Toohey, D. W., Flynn, J. H., Lefer, B. L., Grossberg, N., Alvarez, S., Rappenglück, B., Taylor, J. W., Allan, J. D., Holloway, J. S., Gilman, J. B., Kuster, W. C., de Gouw, J. A., Massoli, P., Zhang, X., Liu, J., Weber, R. J., Corrigan, A. L., Russell, L. M., Isaacman, G., Worton, D. R., Kreisberg, N. M., Goldstein, A. H., Thalman, R., Waxman, E. M., Volkamer, R., Lin, Y. H., Surratt, J. D., Kleindienst, T. E., Offenberg, J. H., Dusanter, S., Griffith, S., Stevens, P. S., Brioude, J., Angevine, W. M., and Jimenez, J. L.: Organic aerosol composition and sources in Pasadena, California during the 2010 CalNex campaign, J. Geophys. Res., 118, 9233-9257, doi:10.1002/jgrd.50530, 2013.

He, K., Yang, F., Ma, Y., Zhang, Q., Yao, X., Chan, C. K., Cadle, S., Chan, T., and Mulawa, P.: The characteristics of PM2.5 in Beijing, China, Atmos. Environ., 35, 4959-4970, doi:10.1016/s1352-2310(01)00301-6, 2001.

He, L.-Y., Huang, X.-F., Xue, L., Hu, M., Lin, Y., Zheng, J., Zhang, R., and Zhang, Y.-H.: Submicron aerosol analysis and organic source apportionment in an urban atmosphere in Pearl River Delta of China using high-resolution aerosol mass spectrometry, J. Geophys. Res., 116, D12304, doi:10.1029/2010jd014566, 2011.

He, L. Y., Lin, Y., Huang, X. F., Guo, S., Xue, L., Su, Q., Hu, M., Luan, S. J., and Zhang, Y. H.: Characterization of high-resolution aerosol mass spectra of primary organic aerosol emissions from Chinese cooking and biomass burning, Atmos. Chem. Phys., 10, 11535-11543, doi:10.5194/acp-10-11535-2010, 2010.

Heald, C. L., Kroll, J. H., Jimenez, J. L., Docherty, K. S., DeCarlo, P. F., Aiken, A. C., Chen, Q., Martin, S. T., Farmer, D. K., and Artaxo, P.: A Simplified Description of the Evolution of Organic Aerosol Composition in the Atmosphere, Geophys. Res. Lett., 37, L08803, doi:10.1029/2010g1042737, 2010.

Herndon, S. C., Onasch, T. B., Wood, E. C., Kroll, J. H., Canagaratna, M. R., Jayne, J. T., Zavala, M. A., Knighton, W. B., Mazzoleni, C., Dubey, M. K., Ulbrich, I. M., Jimenez, J. L., Seila, R., de Gouw, J. A., de Foy, B., Fast, J., Molina, L. T., Kolb, C. E., and Worsnop, D. R.: Correlation of secondary organic aerosol with odd oxygen in Mexico City, Geophys. Res. Lett., 35, L15804, doi:10.1029/2008GL034058, 2008.

Hodzic, A., Kasibhatla, P. S., Jo, D. S., Cappa, C. D., Jimenez, J. L., Madronich, S., and Park, R. J.: Rethinking the Global Secondary Organic Aerosol (Soa) Budget: Stronger Production, Faster Re- 
moval, Shorter Lifetime, Atmos. Chem. Phys., 16, 7917-7941, doi:10.5194/acp-16-7917-2016, 2016.

Hu, W. W., Hu, M., Yuan, B., Jimenez, J. L., Tang, Q., Peng, J. F., Hu, W., Shao, M., Wang, M., Zeng, L. M., Wu, Y. S., Gong, Z. H., Huang, X. F., and He, L. Y.: Insights on organic aerosol aging and the influence of coal combustion at a regional receptor site of central eastern China, Atmos. Chem. Phys., 13, 10095-10112, doi:10.5194/acp-13-10095-2013, 2013.

Hu, W., Hu, M., Hu, W., Jimenez, J. L., Yuan, B., Chen, W., Wang, M., Wu, Y., Chen, C., Wang, Z., Peng, J., Zeng, L., and Shao, M.: Chemical Composition, Sources, and Aging Process of Submicron Aerosols in Beijing: Contrast between Summer and Winter, J. Geophys. Res., 121, 2015JD024020, doi:10.1002/2015JD024020, 2016.

Huang, R.-J., Zhang, Y., Bozzetti, C., Ho, K.-F., Cao, J.-J., Han, Y., Daellenbach, K. R., Slowik, J. G., Platt, S. M., Canonaco, F., Zotter, P., Wolf, R., Pieber, S. M., Bruns, E. A., Crippa, M., Ciarelli, G., Piazzalunga, A., Schwikowski, M., Abbaszade, G., SchnelleKreis, J., Zimmermann, R., An, Z., Szidat, S., Baltensperger, U., Haddad, I. E., and Prevot, A. S. H.: High secondary aerosol contribution to particulate pollution during haze events in China, Nature, 514, 218-222, doi:10.1038/nature13774, 2014

Huang, X.-F., Xue, L., Tian, X.-D., Shao, W.-W., Sun, T.-L., Gong, Z.-H., Ju, W.-W., Jiang, B., Hu, M., and He, L.Y.: Highly time-resolved carbonaceous aerosol characterization in Yangtze River Delta of China: Composition, mixing state and secondary formation, Atmos. Environ., 64, 200-207, doi:10.1016/j.atmosenv.2012.09.059, 2013.

Huang, X. F., He, L. Y., Hu, M., Canagaratna, M. R., Kroll, J. H., Ng, N. L., Zhang, Y. H., Lin, Y., Xue, L., Sun, T. L., Liu, X. G., Shao, M., Jayne, J. T., and Worsnop, D. R.: Characterization of submicron aerosols at a rural site in Pearl River Delta of China using an Aerodyne High-Resolution Aerosol Mass Spectrometer, Atmos. Chem. Phys., 11, 1865-1877, doi:10.5194/acp-11-18652011, 2011.

Ianniello, A., Spataro, F., Esposito, G., Allegrini, I., Hu, M., and Zhu, T.: Chemical characteristics of inorganic ammonium salts in PM2.5 in the atmosphere of Beijing (China), Atmos. Chem. Phys., 11, 10803-10822, doi:10.5194/acp-11-10803-2011, 2011.

Jayne, J. T., Leard, D. C., Zhang, X., Davidovits, P., Smith, K. A., Kolb, C. E., and Worsnop, D. R.: Development of an Aerosol Mass Spectrometer for Size and Composition Analysis of Submicron Particles, Aerosol. Sci. Technol., 33, 49-70, doi:10.1080/027868200410840, 2000.

Jimenez, J. L., Canagaratna, M. R., Donahue, N. M., Prevot, A. S. H., Zhang, Q., Kroll, J. H., DeCarlo, P. F., Allan, J. D., Coe, H., Ng, N. L., Aiken, A. C., Docherty, K. S., Ulbrich, I. M., Grieshop, A. P., Robinson, A. L., Duplissy, J., Smith, J. D., Wilson, K. R., Lanz, V. A., Hueglin, C., Sun, Y. L., Tian, J., Laaksonen, A., Raatikainen, T., Rautiainen, J., Vaattovaara, P., Ehn, M., Kulmala, M., Tomlinson, J. M., Collins, D. R., Cubison, M. J., E., Dunlea, J., Huffman, J. A., Onasch, T. B., Alfarra, M. R., Williams, P. I., Bower, K., Kondo, Y., Schneider, J., Drewnick, F., Borrmann, S., Weimer, S., Demerjian, K., Salcedo, D., Cottrell, L., Griffin, R., Takami, A., Miyoshi, T., Hatakeyama, S., Shimono, A., Sun, J. Y., Zhang, Y. M., Dzepina, K., Kimmel, J. R., Sueper, D., Jayne, J. T., Herndon, S. C., Trimborn, A. M., Williams, L. R., Wood, E. C., Middlebrook, A. M., Kolb, C. E., Baltensperger, U., and Worsnop, D. R.: Evolution of organic aerosols in the atmosphere, Science, 326, 1525-1529, doi:10.1126/science.1180353, 2009.

Liu, Z., Wang, Y., Vrekoussis, M., Richter, A., Wittrock, F., Burrows, J. P., Shao, M., Chang, C.-C., Liu, S.-C., Wang, H., and Chen, C.: Exploring the missing source of glyoxal (CHOCHO) over China, Geophys. Res. Lett., 39, L10812, doi:10.1029/2012GL051645, 2012.

Minguillón, M. C., Perron, N., Querol, X., Szidat, S., Fahrni, S. M., Alastuey, A., Jimenez, J. L., Mohr, C., Ortega, A. M., Day, D. A., Lanz, V. A., Wacker, L., Reche, C., Cusack, M., Amato, F., Kiss, G., Hoffer, A., Decesari, S., Moretti, F., Hillamo, R., Teinilä, K., Seco, R., Peñuelas, J., Metzger, A., Schallhart, S., Müller, M., Hansel, A., Burkhart, J. F., Baltensperger, U., and Prévôt, A. S. H.: Fossil vs.F contemporary sources of fine elemental and organic carbonaceous particulate matter during the DAURE campaign in Northeast Spain, Atmos. Chem. Phys., 11, 12067-12084, doi:10.5194/acp-11-12067-2011, 2011.

Mohr, C., DeCarlo, P. F., Heringa, M. F., Chirico, R., Slowik, J. G., Richter, R., Reche, C., Alastuey, A., Querol, X., Seco, R., Penuelas, J., Jimenez, J. L., Crippa, M., Zimmermann, R., Baltensperger, U., and Prevot, A. S. H.: Identification and quantification of organic aerosol from cooking and other sources in Barcelona using aerosol mass spectrometer data, Atmos. Chem. Phys., 12, 1649-1665, doi:10.5194/acp-12-1649-2012, 2012.

Ng, N. L., Canagaratna, M. R., Zhang, Q., Jimenez, J. L., Tian, J., Ulbrich, I. M., Kroll, J. H., Docherty, K. S., Chhabra, P. S., Bahreini, R., Murphy, S. M., Seinfeld, J. H., Hildebrandt, L., Donahue, N. M., DeCarlo, P. F., Lanz, V. A., Prévôt, A. S. H., Dinar, E., Rudich, Y., and Worsnop, D. R.: Organic aerosol components observed in Northern Hemispheric datasets from Aerosol Mass Spectrometry, Atmos. Chem. Phys., 10, 46254641, doi:10.5194/acp-10-4625-2010, 2010.

Okuda, T., Naoi, D., Tenmoku, M., Tanaka, S., He, K., Ma, Y., Yang, F., Lei, Y., Jia, Y., and Zhang, D.: Polycyclic Aromatic Hydrocarbons (Pahs) in the Aerosol in Beijing, China, Measured by Aminopropylsilane ChemicallyBonded Stationary-Phase Column Chromatography and Hplc/Fluorescence Detection, Chemosphere, 65, 427-435, doi:10.1016/j.chemosphere.2006.01.064, 2006.

Ortega, A. M., Day, D. A., Cubison, M. J., Brune, W. H., Bon, D., de Gouw, J. A., and Jemenez, J. L., Secondary organic aerosol formation and primary organic aerosol oxidation from biomass-burning smoke in a flow reactor during FLAME-3, Atmos. Chem. Phys., 13, 11551-11571, doi:10.5194/acp-1311551-2013, 2013.

Paatero, P. and Tapper, U.: Positive matrix factorization: A non-negative factor model with optimal utilization of error estimates of data values, Environmetrics, 5, 111-126, doi:10.1002/env.3170050203, 1994.

Pusede, S. E., VandenBoer, T. C., Murphy, J. G., Markovic, M. Z., Young, C. J., Veres, P. R., Roberts, J. M., Washenfelder, R. A., Brown, S. S., Ren, X., Tsai, C., Stutz, J., Brune, W. H., Browne, E. C., Wooldridge, P. J., Graham, A. R., Weber, R., Goldstein, A. H., Dusanter, S., Griffith, S. M., Stevens, P. S., Lefer, B. L., and Cohen, R. C.: An Atmospheric Constraint on the $\mathrm{NO}_{2}$ Dependence of Daytime near-Surface Nitrous Acid (Hono), Environ. Sci. Technol., 49, 12774-12781, doi:10.1021/acs.est.5b02511, 2015 . 
Song, Y., Xie, S., Zhang, Y., Zeng, L., Salmon, L. G., and Zheng, M.: Source apportionment of PM2.5 in Beijing using principal component analysis/absolute principal component scores and UNMIX, Sci. Total. Environ., 372, 278-286, doi:10.1016/j.scitotenv.2006.08.041, 2006.

Sun, Y., Du, W., Fu, P., Wang, Q., Li, J., Ge, X., Zhang, Q., Zhu, C., Ren, L., Xu, W., Zhao, J., Han, T., Worsnop, D. R., and Wang, Z.: Primary and secondary aerosols in Beijing in winter: sources, variations and processes, Atmos. Chem. Phys., 16, 8309-8329, doi:10.5194/acp-16-8309-2016, 2016.

Sun, Y., Jiang, Q., Wang, Z., Fu, P., Li, J., Yang, T., and Yin, Y.: Investigation of the sources and evolution processes of severe haze pollution in Beijing in January 2013, J. Geophys. Res., 119, 2014JD021641, doi:10.1002/2014JD021641, 2014.

Sun, Y., Zhuang, G., Tang, A., Wang, Y., and An, Z.: Chemical Characteristics of $\mathrm{PM}_{2.5}$ and $\mathrm{PM}_{10}$ in Haze-Fog Episodes in Beijing, Environ. Sci. Technol., 40, 3148-3155, doi:10.1021/es051533g, 2006.

Sun, Y., Zhang, Q., Zheng, M., Ding, X., Edgerton, E. S., and Wang, $\mathrm{X}$.: Characterization and source apportionment of water-soluble organic matter in atmospheric fine particles $\left(\mathrm{pm}_{2.5}\right)$ with highresolution aerosol mass spectrometry and gc-ms, Environ. Sci. Technol., 45, 4854-4861, doi:10.1021/es200162h, 2011a.

Sun, Y., Zhang, Q., Schwab, J. J., Demerjian, K. L., Chen, W. N., Bae, M. S., Hung, H. M., Hogrefe, O., Frank, B., Rattigan, O. V., and Lin, Y. C.: Characterization of the sources and processes of organic and inorganic aerosols in New York city with a high-resolution time-of-flight aerosol mass apectrometer, Atmos. Chem. Phys., 11, 1581-1602, doi:10.5194/acp-11-15812011, 2011b.

Sun, Y. L., Wang, Z., Fu, P., Jiang, Q., Yang, T., Li, J., and Ge, $\mathrm{X}$. : The impact of relative humidity on aerosol composition and evolution processes during wintertime in Beijing, China, Atmos. Environ., 77, 927-934, doi:10.1016/j.atmosenv.2013.06.019, 2013a.

Sun, Y. L., Wang, Z. F., Fu, P. Q., Yang, T., Jiang, Q., Dong, H. B., Li, J., and Jia, J. J.: Aerosol composition, sources and processes during wintertime in Beijing, China, Atmos. Chem. Phys., 13, 4577-4592, doi:10.5194/acp-13-4577-2013, 2013 b.

Szidat, S., Salazar, G. A., Vogel, E., Battaglia, M., Wacker, L., Synal, H. A., and Türler, A.: ${ }^{14} \mathrm{C}$ analysis and sample preparation at the new Bern Laboratory for the Analysis of Radiocarbon with AMS (LARA), Radiocarbon, 56, 561-566, doi:10.2458/56.17457, 2014.

Tang, X. Y., Tian, B. S., Chen, C. H., and Ren, Z. H.: A study of photochemical smog pollution and its control stratiges at $\mathrm{Xi}-\mathrm{Gu}$ district of Lanzhou city, China, Environ. Sci., 5, 1-11, 1985 (in Chinese with Eglish abstract).

Ulbrich, I. M., Canagaratna, M. R., Zhang, Q., Worsnop, D. R., and Jimenez, J. L.: Interpretation of organic components from Positive Matrix Factorization of aerosol mass spectrometric data, Atmos. Chem. Phys., 9, 2891-2918, doi:10.5194/acp-9-2891-2009, 2009.

Volkamer, R., Jimenez, J. L., San Martini, F., Dzepina, K., Zhang, Q., Salcedo, D., Molina, L. T., Worsnop, D. R., and Molina, M. J.: Secondary organic aerosol formation from anthropogenic air pollution: Rapid and higher than expected, Geophys. Res. Lett., 33, L17811, doi:10.1029/2006GL026899, 2006.
Wang, X., Cotter, E., Iyer, K. N., Fang, J., Williams, B. J., and Biswas, P.: Relationship between pyrolysis products and organic aerosols formed during coal combustion, P. Combust. Inst., 35, 2347-2354, doi:10.1016/j.proci.2014.07.073, 2015.

Wang, Y., Ying, Q., Hu, J., and Zhang, H.: Spatial and temporal variations of six criteria air pollutants in 31 provincial capital cities in China during 2013-2014, Environ. Int., 73, 413-422, doi:10.1016/j.envint.2014.08.016, 2014.

Wiedensohler, A., Birmili, W., Nowak, A., Sonntag, A., Weinhold, K., Merkel, M., Wehner, B., Tuch, T., Pfeifer, S., Fiebig, M., Fjäraa, A. M., Asmi, E., Sellegri, K., Depuy, R., Venzac, H., Villani, P., Laj, P., Aalto, P., Ogren, J. A., Swietlicki, E., Williams, P., Roldin, P., Quincey, P., Hüglin, C., Fierz-Schmidhauser, R., Gysel, M., Weingartner, E., Riccobono, F., Santos, S., Grüning, C., Faloon, K., Beddows, D., Harrison, R., Monahan, C., Jennings, S. G., O’Dowd, C. D., Marinoni, A., Horn, H. G., Keck, L., Jiang, J., Scheckman, J., McMurry, P. H., Deng, Z., Zhao, C. S., Moerman, M., Henzing, B., de Leeuw, G., Löschau, G., and Bastian, S.: Mobility particle size spectrometers: harmonization of technical standards and data structure to facilitate high quality long-term observations of atmospheric particle number size distributions, Atmos. Meas. Tech., 5, 657-685, doi:10.5194/amt5-657-2012, 2012.

Wood, E. C., Canagaratna, M. R., Herndon, S. C., Onasch, T. B., Kolb, C. E., Worsnop, D. R., Kroll, J. H., Knighton, W. B., Seila, R., Zavala, M., Molina, L. T., DeCarlo, P. F., Jimenez, J. L., Weinheimer, A. J., Knapp, D. J., Jobson, B. T., Stutz, J., Kuster, W. C., and Williams, E. J.: Investigation of the correlation between odd oxygen and secondary organic aerosol in Mexico City and Houston, Atmos. Chem. Phys., 10, 8947-8968, doi:10.5194/acp-10-8947-2010, 2010.

Xu, J., Zhang, Q., Chen, M., Ge, X., Ren, J., and Qin, D.: Chemical composition, sources, and processes of urban aerosols during summertime in northwest China: insights from high-resolution aerosol mass spectrometry, Atmos. Chem. Phys., 14, 1259312611, doi:10.5194/acp-14-12593-2014, 2014.

Young, C. J., Washenfelder, R. A., Roberts, J. M., Mielke, L. H., Osthoff, H. D., Tsai, C., Pikelnaya, O., Stutz, J., Veres, P. R., Cochran, A. K., VandenBoer, T. C., Flynn, J., Grossberg, N., Haman, C. L., Lefer, B., Stark, H., Graus, M., de Grouw, J., Gilman, J. B., Kuster, W. C., and Brown, S. S.: Vertically resolved measurements of nighttime radical reservoirs in Los Angeles and their contribution to the urban radical budget, Environ. Sci. Technol., 46, 10965-10973, doi:10.1021/es302206a, 2012.

Young, D. E., Kim, H., Parworth, C., Zhou, S., Zhang, X., Cappa, C. D., Seco, R., Kim, S., and Zhang, Q.: Influences of emission sources and meteorology on aerosol chemistry in a polluted urban environment: results from DISCOVER-AQ California, Atmos. Chem. Phys., 16, 5427-5451, 10.5194/acp-16-5427-2016, 2016.

Yu, L., Wang, G., Zhang, R., Zhang, L., Song, Y., Wu, B., Li, X., An, K., and Chu, J.: Characterization and Source Apportionment of $\mathrm{PM}_{2.5}$ in an Urban Environment in Beijing, Aerosol Air Qual. Res., 13, 574-583, doi:10.4209/aaqr.2012.07.0192, 2013.

Zhang, J. K., Sun, Y., Liu, Z. R., Ji, D. S., Hu, B., Liu, Q., and Wang, Y. S.: Characterization of submicron aerosols during a month of serious pollution in Beijing, 2013, Atmos. Chem. Phys., 14, 2887-2903, doi:10.5194/acp-14-2887-2014, 2014. 
Zhang, L., Chen, C., Li, S., and Zhang, F.: Air pollution and potential control schemes in Lanzhou, Res. Environ. Sci., 13, 18-21, 2000.

Zhang, Q., Canagaratna, M. R., Jayne, J. T., Worsnop, D. R., and Jimenez, J. L.: Time- and size-resolved chemical composition of submicron particles in Pittsburgh: Implications for aerosol sources and processes, J. Geophys. Res., 110, D07s09, doi:10.1029/2004jd004649, 2005.

Zhang, Q., Jimenez, J. L., Canagaratna, M. R., Ulbrich, I. M., Ng, N. L., Worsnop, D. R., and Sun, Y.: Understanding atmospheric organic aerosols via factor analysis of aerosol mass spectrometry: a review, Anal. Bioanal. Chem., 401, 3045-3067, doi:10.1007/s00216-011-5355-y, 2011.

Zhang, Q. and Li, H.: A studay of the relationship between air pollutants and inversion in the ABL over the city of Lanzhou, Adv. Atmos. Sci., 28, 879-886, doi:10.1007/s00376-010-0079-z, 2011.

Zhang, R., Jing, J., Tao, J., Hsu, S. C., Wang, G., Cao, J., Lee, C. S. L., Zhu, L., Chen, Z., Zhao, Y., and Shen, Z.: Chemical characterization and source apportionment of $\mathrm{PM}_{2.5}$ in Beijing: seasonal perspective, Atmos. Chem. Phys., 13, 7053-7074, doi:10.5194/acp-13-7053-2013, 2013.

Zhang, Y., Schauer, J. J., Zhang, Y., Zeng, L., Wei, Y., Liu, Y., and Shao, M.: Characteristics of Particulate Carbon Emissions from Real-World Chinese Coal Combustion, Environ. Sci. Technol., 42, 5068-5073, doi:10.1021/es7022576, 2008.

Zhang, Y. J., Tang, L. L., Wang, Z., Yu, H. X., Sun, Y. L., Liu, D., Qin, W., Canonaco, F., Prévôt, A. S. H., Zhang, H. L., and Zhou, H. C.: Insights into characteristics, sources, and evolution of submicron aerosols during harvest seasons in the Yangtze River delta region, China, Atmos. Chem. Phys., 15, 1331-1349, doi:10.5194/acp-15-1331-2015, 2015a.

Zhang, Y. L., Huang, R. J., El Haddad, I., Ho, K. F., Cao, J. J., Han, Y., Zotter, P., Bozzetti, C., Daellenbach, K. R., Canonaco, F., Slowik, J. G., Salazar, G., Schwikowski, M., Schnelle-Kreis, J., Abbaszade, G., Zimmermann, R., Baltensperger, U., Prévôt, A. S. H., and Szidat, S.: Fossil vs. Non-fossil sources of fine carbonaceous aerosols in four chinese cities during the extreme winter haze episode of 2013, Atmos. Chem. Phys., 15, 1299-1312, 10.5194/acp-15-1299-2015, 2015b.
Zhang, Y. L., Perron, N., Ciobanu, V. G., Zotter, P., Minguillón, M. C., Wacker, L., Prévôt, A. S. H., Baltensperger, U., and Szidat, S.: On the isolation of OC and EC and the optimal strategy of radiocarbon-based source apportionment of carbonaceous aerosols, Atmos. Chem. Phys., 12, 10841-10856, doi:10.5194/acp-12-10841-2012, 2012.

Zhang, Z., Wang, X., Zhang, Y., Lü, S., Huang, Z., Huang, X., and Wang, Y.: Ambient air benzene at background sites in China's most developed coastal regions: Exposure levels, source implications and health risks, Sci. Total. Environ., 511, 792-800, doi:10.1016/j.scitotenv.2015.01.003, 2015c.

Zhao, X. J., Zhao, P. S., Xu, J., Meng, W., Pu, W. W., Dong, F., He, D., and Shi, Q. F.: Analysis of a winter regional haze event and its formation mechanism in the North China Plain, Atmos. Chem. Phys., 13, 5685-5696, doi:10.5194/acp-13-5685-2013, 2013.

Zheng, G. J., Duan, F. K., Su, H., Ma, Y. L., Cheng, Y., Zheng, B., Zhang, Q., Huang, T., Kimoto, T., Chang, D., Pöschl, U., Cheng, Y. F., and He, K. B.: Exploring the severe winter haze in Beijing: the impact of synoptic weather, regional transport and heterogeneous reactions, Atmos. Chem. Phys., 15, 2969-2983, doi:10.5194/acp-15-2969-2015, 2015.

Zheng, M., Salmon, L. G., Schauer, J. J., Zeng, L., Kiang, C. S., Zhang, Y., and Cass, G. R.: Seasonal trends in PM2.5 source contributions in Beijing, China, Atmos. Environ., 39, 3967-3976, doi:10.1016/j.atmosenv.2005.03.036, 2005.

Zotter, P., El-Haddad, I., Zhang, Y., Hayes, P. L., Zhang, X., Lin, Y.-H., Wacker, L., Schnelle-Kreis, J., Abbaszade, G., Zimmermann, R., Surratt, J. D., Weber, R., Jimenez, J. L., Szidat, S., Baltensperger, U., and Prévôt, A. S. H.: Diurnal cycle of fossil and nonfossil carbon using radiocarbon analyses during CalNex, J. Geophys. Res.-Atmos., 119, 6818-6835, doi:10.1002/2013JD021114, 2014. 